\title{
SURÁNYI BÉLA
}

\section{A MAGYAR MEZŐGAZDASÁGI SZAKOKTATÁS TÖRTÉNETE 1945-IG, KÜLÖNÖS TEKINTETTEL A DEBRECENI AGRÁR-FELSŐOKTATÁSRA}

\begin{abstract}
THE History of Hungarian AgRiCUltural Vocational EDUCATION UNTIL 1945, with a SPECIAL EMPHASIS on the Agricultural Higher EDUCATion of Debrecen. The study mainly provides an overview on the organizational history of educational institutions of the Hungarian agricultural vocational education. It gives a perspective on the development of different types of schools from the lowest level of education, through secondary education to the institutions of the highest level, outlining the economic and social-historical aspects, also with respect to the relevant legislation. A special attention is paid by the author to the history of the agricultural higher education of Debrecen until 1945.
\end{abstract}

Másfél évszázaddal ezelőtt nyitotta meg kapuit a Debreceni Magyar Királyi Felsőbb Gazdasági Tanintézet és a Földműves Iskola. Az évforduló alkalmat nyújt egyrészt az ünneplésre, másrészt a számvetésre, hiszen hosszú utat tett meg az intézmény 1868. október 22-től, az első tanévnyitói programbeszédtől, napjainkig. Nemcsak a szűkebb pátriában, hanem az ország agrárszakember képzésében, a mezőgazdasági kutatásban is jelentős pályát futott be, elismerésre méltó rangot vívott ki magának. Gyorsan felzárkózott a korábbi alapítású szakképzés fellegvárai (Keszthely, Magyaróvár) mellé. Debrecen színrelépésének kedvezett az 1867-es kiegyezés, a város cívis polgárainak törekvése, mezőgazdaságának hagyományai, amely utóbbi egyszerre volt megőrző és az új iránt fogékony. Mindennek alapja a Max Weber ${ }^{1}$ által megfogalmazott etikai tétel, a tisztes anyagi gyarapodás, amely Németalföldet, az angolszász protestáns világot a korabeli fejlődés motorjává tette.

Debrecen első példája lett annak a modellnek, amelyre az állam szerepvállalása volt jellemző. Mindez egyúttal fordulópontot jelentett a mezőgazdasági szakképzés hazai történetében, amit egyrészt a szakoktatás szükségességének felismerése - mindez magába foglalta a város vezetésének és gazdatársadalmának törekvését - másrészt az állam e téren folytatott tevékenysége jellemzett.

A debreceni agrárfelsőoktatás múltjának feldolgozását az intézmény már kezdettől fogva feladatának tekintette. Ennek jegyében az összefoglaló művek egész sora született meg az évtizedek során. A 19. század utolsó harmadában a tanintézet által kiadott

\footnotetext{
${ }^{1}$ Max Weber, A protestáns etika és a kapitalizmus szelleme, Budapest, 1982, 534. „a kálvini reformáció a genfi, a hollandiai, a skóciai republikánusoknak zászlóul szolgált, felszabadította Hollandiát [illetve ideológiai háttere volt az angol polgári forradalomnak].
} 
évkönyvek szinte minden évben rövid áttekintést adtak az alapítástól megtett útról. Bővebb áttekintések láttak napvilágot 1920 után, amelyek biztos forrásként szolgálnak az oktatás, a kutatás, az intézménynek a közéletben betöltött szerepe terén. Az önálló intézménytörténeti munkák a 20. század második felében váltak általánossá. ${ }^{2}$

2018-ban a Debreceni Egyetem Mezőgazdasági Kara fennállásának 150 éves időszakát ünnepli. Önálló kötet kap nyomdafestéket, amely bemutatja a másfél évszázadot, a megtett utat, az oktatási és kutatási eredményeket, az iskolateremtő tanáregyéniségeket, a szűkebb-tágabb pátriában, sőt nemzetközi szintéren is betöltött szerepet. Konferenciák megrendezésére is sor kerül az év folyamán, ezzel is öregbítve az intézmény hírnevét, jelezve, hogy Debrecen az agrártudományok, az élelmiszertudomány és a környezetgazdálkodás egyetemi oktatásának egyik vezető fellegvára.

Egy másfél évtizeddel korábban megjelent tanulmányának átdolgozásával tiszteleg a szerző e nagyhírű intézmény szellemisége előtt, felvázolva a debreceni agrárfelsőoktatás múltját, beágyazva a Kárpát-medence mezőgazdasági szakképzésébe. ${ }^{3}$

\section{A mezögazdasági szakoktatás jelentösége}

A több mint ezeréves magyar oktatástörténetben viszonylag későn jelent meg a mezőgazdasági szakoktatás, így nincsenek olyan történelmi gyökerei, mint pl. a céhes keretek között folyó utánpótlás-nevelésnek vagy a már a középkorban felbukkanó, a polgárság érdekeit szolgáló, a városi iskolákhoz kötődő ipari-kereskedelmi képzésnek.

A mezőgazdasági ismeretátadás, a paraszti népesség „szakképzése” a 16-17. századig kizárólag a család, a helyi közösség privilégiuma közé tartozott. De a gazdálkodás tapasztalati kultúrájának nemzedéki sorjázása még sokáig létezett az intézményes szakoktatást követően is. A parasztság körében meglévő nemzedéki tapasztalatok mindig nagyobb súllyal estek latba, mint az újdonság gyakorlatban még nem tapasztalt előnye.

De a korszerű gazdálkodás elsajátításában az idő haladtával egyre nagyobb teret töltött be a széleskörü, tudományos alapokon nyugvó ismeret megszerzése. Míg NyugatEurópában már jóval korábban, addig Magyarországon a 18-19. század fordulójától

\footnotetext{
${ }^{2}$ A debreceni agrár-felsöoktatás 100 éve, szerk. Komoróczy György, Budapest, 1968; A Debreceni Agrártudományi Föiskola centenáriumi ünnepségei (1868-1968), Debrecen, 1968; Bencsik István, A Debreceni Agrártudományi Föiskola 10 éve (1953-1963), Debrecen, 1969; A Debreceni Agrártudományi Egyetem 125 éve. I-III., föszerk. SzÁsz Gábor, Debrecen, 1992-1994; Az egyetem alapitásának 125. évfordulójára rendezett szimpózium: elöadások és poszterek kivonatai, föszerk. SzÁsz Gábor, Debrecen, 1993; 135 éves a debreceni agrárfelsőoktatás, szerk. SzÁsz Gábor-SzÉKeLynÉ Sipos Klára-Jávor András, Debrecen, 2003; 140 éves a debreceni gazdasági és agrárfelsőoktatás, szerk. FüRJNÉ RáDI Katalin, Debrecen, 2008; A Debreceni Egyetem története (1912-2012), szerk. Orosz István-ifj. BarTa János, Debrecen, 2012.

3 Déri Múzeum évkönyve 2004, Debrecen, 2005, 343-370.
} 
jelentősen megváltozott a mezőgazdaság megítélése, amelyről kiderült, hogy „[...] most már nem olyan könnyü foglalkozás [...] mit a fiú az apától kevés fáradsággal megtanulhatott. A modern gazdaság hosszú, tudományos elökészültséget, fárasztó tanulmányozást és sokoldalú beavatást igényel mindazoktól, kik kelló sikerrel gyakorolni óhajtják" - írja 1874-ben Sporzon Pál, aki a keszthelyi Georgikon igazgatójaként és tanáraként jelentősen hozzájárult a háromszintű mezőgazdasági szakoktatás hazai megindulásához. ${ }^{4}$

A magyar mezőgazdasági szakoktatás viszonylag rövid múltja ellenére azonban bővelkedett időbeli prioritásokban, a nemzeti érdeket szolgáló messzemenő tervekben, törekvésekben, de azok megvalósításában is.

A kiegyezést követő évtizedek alatt vált rangjához méltóvá a hazai mezőgazdasági szakképzés, kikerülve az egyéni kezdeményezés és emberi tenni akarás sokszor szűknek bizonyuló köréből, amely az esetlegesség jegyeit hordozta magában és főként állami szerepvállalással, intézményi keretek között a nemzetgazdaság meghatározó ágazatának szellemi hátterévé nőtte ki magát.

A hazai oktatásba való „beágyazódása” nem volt zökkenőmentes, önálló képzési területként sem mindig felelt meg az elvárásoknak. A reformok, az útkeresés eredményei nem mindig tükrözték a jobbítás eredeti szándékát, amire utal a 19-20. század fordulóján bevezetett agrárfelsőoktatási reform is, melynek során „[...] a tanintézetek akadémiává nyilvánitása [...] többnyire... csak a cégtábla átfestését jelentette [...] Az elméleti alapképzésben hiányok mutatkoztak (a tantervben nem szerepelt a matematika, a talajtan és a biológia, a kémiai oktatás keretei pedig szükek voltak), továbbá nem bizonyult megfelelönek a gyakorlati képzés tantervi elhelyezése sem." "A termelési követelményekhez többé-kevésbé igazodó mezőgazdasági szakoktatás általános problémái ugyanúgy föllelhetők voltak a közép- és alsó fokú szakképzésben is, anélkül, hogy kétségbe vonnánk az 1867-1944 közötti korszak eredményeit. Bár a 20. században már bizonyos hangsúlyeltolódás volt tapasztalható a háromszintű képzés egyes területei között - elsősorban az 1920-as évek után - de föleg „[...] a nagybirtok vezetésére képeztek ki intézóket, ennek megfelelöen aránytalan volt a föiskolák súlya a közép-és föként (az) alsó fokú szakiskolákhoz képest. Leggyengébb a középfokú szakoktatás volt (az 1930-as évektöl már jóval nagyobb szerepet játszott), holott ennek fejlesztésére lett volna talán a legnagyobb szükség."

\section{A magyar mezögazdasági szakoktatás gyökerei}

Európa, így Magyarország agráriuma is több forrásból táplálkozik. Bár a prehistorikus időszak egyes korszakai között nincs - eddigi ismereteink szerint - folyamatosság, de hatásuk bizonyára nem múlt el nyomtalanul. Annál nagyobb - egyúttal tudományosan

\footnotetext{
${ }^{4}$ Sporzon Pál, Emlékirat a hazai gazdasági tanügy tárgyában, Keszthely, 1874, 7.

5 LADÁNYI Andor, A magyar felsöoktatás a XX. században, Budapest, 1999, 24-25.

${ }^{6}$ A földmüvelésügyi szakigazgatás története 1867-1948, szerk. Pataky Ernő, Budapest, 1970, 59.
} 
is igazolt - szerepet játszott a római örökség, ${ }^{7}$ a népvándorlás századainak hozadéka, a magyarság agrárismerete, ${ }^{8}$ a hittérítő szerzetesek - elsősorban bencések és ciszterciták - gyakorlati tudása, ${ }^{9}$ a bizánci egyházzal fenntartott kapcsolatok, a belső és külső migráció (kiválttépp a 18. században) és az Újvilág felfedezésének „hozománya”. ${ }^{10} \mathrm{~A}$ római örökségtől kezdődően az agrárium elméleti és tapasztalati kultúrája bizonyos folyamatosságot, egymásra épülést és kölcsönhatást mutat. Kiemelendő a monostorok, kolostorok szerepe, melyek századokon át a mezőgazdasági ismeret és termelés meghatározó színterei voltak, megőrizvén az antik hagyományokat, különösen a kertkultúrában. A kolostori agrárkultúrában, mint mintagazdaságban élt tovább az antik világ öröksége. A Kr. u. 795-ben kiadott Capitulare de villis előírásaiban jól ötvöződött a rómaiak és a koraközépkor gazdálkodása. A zöldség, szőlő- és gyümölcstermesztés ismeretanyaga a szerzetesek közvetítésével jórészt a paraszti kertkultúrában talált otthonra

A reformáció lendületet adott a reneszánsz szellemiségében a természettudományok fejlődésének, ami a protestáns iskolarendszerben is éreztette hatását. ${ }^{11}$ Comenius J. A. (1592-1670) Orbis sensualium pictus címü munkájában a VIII. fejezet foglalkozik a mezőgazdasággal. A jó nevű pedagógus Sárospatakon szorgalmazta mezőgazdasági jellegű előadások beiktatását a helyi oktatásba. Apáczai Csere János (1625-1659) Magyar Enciklopédiájának VIII. fejezete alapos összeállítás a mezőgazdaságról, amely nemcsak a tanulók, hanem a földművelők számára is hasznos ismereteket tett közzé. Lippai János (1606-1666) pedig azért jelentős a magyar művelödéstörténetben, ${ }^{12}$ mert „,...] munkássága az elsö kisérlet hazánkban az elméleti és a gyakorlati mezögazdaság és kertészet összeegyeztetésére."

A 18. század már a mezőgazdasági szakoktatás formálódásának a jegyében telt el, függetlenül az oktatás szintjétől, az alapítás jellegétől. ${ }^{13}$ Az 1763-ban Szempcen (Pozsony vm.) létesült Collegium Oeconomicum-ot a szakirodalom Európa egyik első számviteli iskolájaként tartja számon, ahol a hallgatók mezőgazdaságtant is tanultak. De említhetnénk még Tallóst (1764), Tatát (1765) vagy Vácot (1769) is, ahol a hallgatók ismerkedtek a gazdálkodás elemeivel is. A korai próbálkozások közé tartozott a Pázmány Péter alapította nagyszombati egyetem, ${ }^{14}$ ahol külön tárgyként szerepelt az agronómia is. Sőt, az egyetem Pestre történő áthelyezésével (1784) a mezőgazdaságtan (Oeconomia ruralis) önálló tanszéket kapott, Mitterpacher Lajos vezetésével. Jóllehet az

\footnotetext{
7 BARTA János, Mezögazdasági irodalom a koraújkori Európában és hatása a magyarországi agrárirodalom alakulására a XVI-XVIII. században, MTA doktori értekezés, 1997, Kézirat 9-46.

${ }^{8}$ A magyar mezögazdaság 1000 éve, szerk. Oroszi Sándor, Budapest, 2000, 5-46.

9 Schmitz, Philibert, A bencések civilizációs tevékenysége a XII. századtól a XX. századig, I., Pannonhalma, 1998, 7-33.

${ }^{10}$ GrigG, D. B., A világ mezögazdasági rendszerei, Budapest, 1980, 39.

${ }^{11}$ FeHÉr Erzsébet, Az oktatás és nevelés története, Budapest, 2002, 25-28.

${ }^{12}$ Heckenast József-Zsinka Józsefné, Szakoktatástörténet. II., Gödöllő, 1986, 39-40.

${ }^{13}$ Uo., 56-58.

${ }^{14}$ CsIKI, i. m., 7-8.
} 
egyetem működése kiállta az idő próbáját, a tanszék fennmaradása azonban kizárólag Mitterpacher személyéhez kötődött, aki 1814-ben elhunyt.

Hasonló múlttal büszkélkedhet Selmecbánya is, ahol 1735-ben indult meg az oktatás, ${ }^{15} \mathrm{~s}$ az 1770. április 14-i királyi rendelettel Bányászati és Kohászati Akadémiaként folytatta tevékenységét, érintve az erdészetet és a földtudományokat is.

A magyar iskolaügy, ezen belül a mezőgazdasági szakoktatás számára is fontos dokumentum született az I. Ratio Educationis kiadásával, ${ }^{16}$ melyben a 178. szakasz 4. fejezete megfogalmazta azt a központi óhajt, hogy „[...] minden vármegyében gazdasági iskola nyittassék és az iffúság gondosan képeztessék" "e téren. Minden hiányosság és ellentmondás dacára, a királyi rendelet ösztönözte a hazai agrárképzést is, mivel Tessedik Sámuel (1742-1820) tevékenysége ${ }^{17}$ beleillett a haza jobbítását célzó reformnemzedék törekvéseibe, amihez még társult Bécs szándéka is. Szarvason saját erőbool életre hívta 1779-ben Európa első gyakorlati földműves iskoláját (Practico oeconomicum institutum). A tanintézet volt az első, amely „[...] föleg mezögazdasági ismeretek terjesztését célozta”. Tessedik szerteágazó munkássága hatással volt a 18. század utolsó évtizedeiben nemcsak a hazai mezőgazdasági kultúrára, hanem a szakoktatásra is.

A reformkor szellemisége vezetette Festetich Györgyöt (1755-1819), ${ }^{18}$ amikor Nagyváthy János és Tessedik Sámuel közremủködésével megalapította Európa első rendszeres gazdasági iskoláját - megelőzve A. Thaer intézményét (Celle-Mögling) amely gazdatisztek képzését tekintette elsődleges feladatának, mind a saját, mind más nagybirtokok számára. A Georgikon lényegében egy „iskolaegyüttest” foglalt magába, a következő egységekkel: gazdatisztképzö (1797), földművesiskola (1798), pristaldeum (1804), erdész- és vadásziskola (1806), kertésziskola (1806), ménesmester- és lovásziskola (1807), mérnökiskola (1808), gazdasszonyképző (1808). ${ }^{19}$

A 18. század utolsó évtizedéhez kötődik a hazai állatorvosi képzés megindulása is, amely a Pestre költözött egyetem orvosi karán állatjárványtani tanszékként kezdte meg működését, II. Józsefnek 1786. december 12-én kiadott rendelete alapján. ${ }^{20} \mathrm{~A}$ században meginduló iskolaalapítási hullám utolsó állomásaként 1799-ben nyitotta meg kapuit a nagyszentmiklósi, Nákó Kristóf alapította „kis mezogazdasági iskola”, amelynek hatóköre kizárólag az uradalomra szorítkozott, az uradalmi jobbágyfiúk oktatására. ${ }^{21}$

\footnotetext{
${ }^{15}$ A magyar felsöoktatás évszázadai, szerk. Kardos József, Budapest, 2000, 36., 38.

16 Heckenast-Zsinka, i. m., 83.

${ }^{17}$ CsiкI, i. m., 9-15., Emlékkönyv a Georgikon alapitásának 200. évfordulójára. I., szerk. FüLöp Éva Mária, Keszthely, 1996. Emlékkönyv a Georgikon alapitásának 200. évfordulójára. II. Adattár (17972000), Keszthely, 2001.

${ }_{18}$ CsiкI, i. m., 16-19; Emlékkönyv a Georgikon alapitásának 200. évfordulójára. I., szerk. FüLöp Éva Mária, Keszthely, 1996. Emlékkönyv a Georgikon alapitásának 200. évfordulójára. II. Adattár (17972000), Keszthely, 2001.

19 A magyar felsöoktatás évszázadai, i. m., 45., 200 éves a magyar állatorvosi felsöoktatás (1787-1987), szerk. Holló Ferenc, Budapest, 1987.

${ }^{20}$ A magyar felsöoktatás évszázadai, i. m., 45., 200 éves a magyar állatorvosi felsöoktatás, i. m.

${ }^{21}$ Heckenast-Zsinka, i. m., 115.
} 
A hazai mezőgazdasági szakoktatás egyik fellegváraként a magyaróvári tanintézet ${ }^{22}$ „etalont” jelentett már megalakulásától kezdve. Albert Kázmér szász-tescheni herceget elsősorban üzleti érdek vezette, amikor életre hívta 1818-ban magánalapítású intézetét, annak ellenére, hogy az alapítólevélben foglaltak szerint a "[...] magyar nemzet iránt érzett hajlandósága és szeretete tanúságául, úgy annak emlékéül, hogy a nemzet körében a helytartói állást több éven (1765-1780) keresztül betöltötte, valamint hogy életének legvirágzóbb szakát itt élte át, a magyar királyság javára. "23 Az oktatás megindításában meghatározó szerep jutott az intézet első igazgatójának, Wittmann Antalnak (1818-1832).

A reformkor kibontakozása éreztette hatását a mezőgazdasági szakképzés terén is, hiszen egyre bővült az iskolák száma. Az oktatás színvonala azonban egyenetlen képet mutatott, $s$ jó néhány intézmény működése csak rövid időre korlátozódott. ${ }^{24}$ Klauzál Imre (1799-1847) vezette a Károlyi Lajos, Batthyány Gusztáv és Kázmér alapította rohonci gazdasági tanintézetet (1839-1841), ahol magyar nyelven kizárólag gyakorlati oktatásban részesültek a leendő gazdatisztek. 1845-48 között Karap Sándor és Diószegi Sámuel földművesiskolája szolgálta Debrecen határában (Zelemér) a magyar oktatásügyet, amely az 1848/49-es harci eseményeknek esett áldozatul. 1846-ban nyitotta meg kapuit Török Sándor szőkehalmi (Cegléd mellett) földművesiskolája. Széchenyi István az 1835-ben megalakult Országos Magyar Gazdasági Egyesület (OMGE) keretében megbízást adott 1837-ben Csapó Dánielnek és Török Jánosnak egy tervezet elkészítésére, ${ }^{25}$ amely többek között egy központi gazdaképző intézet felállítását célozta. A tervezet 1844-ben a pozsonyi országgyülés elé került, de pénz hiányában nem valósult meg, noha néhány évtized múltán Sporzon Pál jóvoltából újra napirendre került, $s$ alapjául szolgált a háromszintű magyar mezőgazdasági szakoktatás kialakításának.

A mezőgazdasági ismeretek oktatása nem hagyta érintetlenül a közoktatást sem, „[...] ezért a néptanitók szakszerü mezögazdasági kiképzésének biztositására 1840-ben Nagykörösön mezögazdasági tanszéket állitottak fel"26 a református egyház kezelésében lévő tanítóképzőben.

\section{A dualizmus korának mezögazdasági szakképzése és Debrecen szerepe}

Az 1849 utáni korszak nemcsak a közoktatásban ${ }^{27}$ - az 1849. október 9-én kibocsátott "Entwurf” révén - hanem a mezőgazdasági szakoktatásban is változást hozott. ${ }^{28}$ Két intézet maradt meg, a nagyszentmiklósi földművesiskola, és a magyaróvári gazdasági

${ }^{22}$ Csini László, Mezögazdasági szakoktatásunk kialakulása, fejlödése és mai helyzete, Budapest, 19432, 33-34.

${ }^{23}$ Bánvárth Sándor, Magyaróvári m. kir. Gazdasági Akadémia az 1926-27. tanévben, Magyaróvár, 1927, 8-9.

${ }^{24}$ CSIKI, i. m., 39-41.

${ }^{25}$ Heckenast-Zsinka, i. m., 118.

${ }^{26}$ CsIKI, i. m., 40.

27 MÉszáros István-Németh András-Pukánszky Béla, Neveléstörténet, Budapest, 2003, 303-306.

${ }^{28}$ CsIKI, i. m., 41. 
tanintézet. A többi a szabadságharc idején beszüntette működését, illetve Világos után a bécsi udvar rendelte el bezárásukat. Magyaróvár második korszaka ${ }^{29} 1850-1869$ közé esik, mely időszak alatt cs. kir. gazdasági felsőbb tanintézetként osztrák felügyelet alá került, és német nyelvủ oktatás folyt benne. Noha Bécs a tanintézet beiskolázási körét kiterjesztette az osztrák örökös tartományokra, a hallgatóság zömét a hazai gazdajelöltek alkották. Annak ellenére, hogy 1867-ben visszaállt a magyar alkotmányosság, Magyaróvár csak 1869 januárjában került a magyar kormány felügyelete alá. A magyar nyelvü oktatás mellett azonban továbbra is megmaradt a német oktatás, amely véglegesen csak az 1884/85. évi tanévtől szűnt meg. ${ }^{30}$

A budai ipartanoda (1846) 1857-ben egyetemi rangot kapott József nádor Műegyetem néven, ${ }^{31}$ amelyben 1858-ban Sporzon Pál mezőgazdasági tanszéket indított útjára, $s$ három évtizedig folytak az előadások e témakörben. E politikailag nehéz helyzetben sem adta föl az OMGE a mezőgazdasági szakoktatás bővítésére, színvonalának javítására tett erőfeszítéseit. Tervei közt szerepelt kilenc gazdasági tanintézet és vármegyénként két-két földművesiskola felállítása. Ez azonban csak terv maradt. Az 1860-as évektől vált alkalmassá a politikai légkör arra, hogy újra indulhassanak a korábbi alapítású, de szünetelő gazdasági tanintézetek, egyúttal újak létesítésére is lehetőség nyílott. ${ }^{32}$

1865-ben ismét fogadott hallgatókat Keszthely, 1869-ben magyar felügyelet alá került Magyaróvár. Az újonnan alapítottak közé tartozott Debrecen (1868), Kolozsmonostor (1869), végül 1874-ben Kassa.

A kertészeti oktatás terén is történt elörelépés. ${ }^{33}$ 1853-ban Entz Ferenc kezdeményezésére megnyílt a Haszonkerteket képző Gyakorlati Tanintézet, amelyben német és magyar nyelven folyt az oktatás. A gyakorlati ismeretek elsajátítására helyezték a hangsúlyt. A későbbi Kertészeti Tanintézet az 1860-ban létesült Kertész és Vincellérképző Gyakorlati Tanintézetből alakult ki, melynek élén szintén Entz Ferenc állt. A kétéves elméleti és gyakorlati tanfolyam során vincellérek, pincemesterek és kertészek kerültek ki az intézetből. A korszak szakoktatási intézményeire általában jellemző volt, hogy gyakorta változott elnevezésük, mintegy igazodván a módosuló követelményekhez. De változott az elnevezésük akkor is, ha netalán más vállalta a fenntartói szerepet. Az esetlegesen bekövetkező névváltozás olykor a reformoknak vagy az intézmény „felértékelődésének" is tulajdonítható volt. Megjegyzendő, hogy 1867 után a mezőgazdasági szakoktatás elsősorban állami feladattá vált, ami többnyire hozzájárult az oktatás színvonalának a javulásához.

A népoktatási törvény (1868. évi XXXVIII. tc.) elfogadásával jelentős feladatot vállalt ${ }^{34} \mathrm{a}$ közoktatás is azzal, hogy valamennyi intézményének kötelezővé tette az alapvető

\footnotetext{
29 BÁNVÁrTH, i. m., 10.

30 Uo., 12.

31 Csiki, i. m., 41-42.

32 Uo., 43-45.

33 Heckenast József-Zsinka Józsefné, Szakoktatástörténet (1850-ig) I., Gödöllő, 1983, 19-20.

34 Uo., 23-24.
} 
mezőgazdasági ismeretek oktatását. Ebben különösen nagy szerep jutott a gazdasági ismétlőiskoláknak és az önálló szaktanítós gazdasági ismétlőiskoláknak. E két iskolatípus megjelenése a 19. század utolsó évtizedére esett. Eredményességüket azonban nagyban rontotta, hogy hiányzott a szakképzett, gazdálkodási ismeretekben jártas tanerő. Ezt a Földművelésügyi Minisztérium (FM) és a Vallás és Közoktatásügyi Minisztérium (VKM) tanfolyamok indításával igyekezett áthidalni. Az alsó fokú mezőgazdasági ismeretterjesztés ${ }^{35}$ szolgálta a nyugat-európai mintára, az 1870-es években Magyarországon is szerveződő vándortanítói hálózat kiépítése, amely összecsengett a korszak neves szakembereinek - pl. Hensch Árpád, Sporzon Pál - elképzeléseivel.

Amint már történt róla említés, ekkoriban egyedül csak a magyaróvári tanintézet működött - a hasonló intézmények közül - folyamatosan. ${ }^{36}$ Szerepét mi sem jelzi jobban, mint az a tény, hogy Bécs az 1874. évi rendeletével akadémiai ranggal ruházta föl.

Keszthelyen az Országos Gazdászati és Erdészeti Tanintézet ${ }^{37}$ újbóli megnyitására 1865-ben került sor, de a tanterem és az oktatói létszámban mutatkozó problémák miatt az intézmény elnevezésében jelzett erdészeti oktatás sohasem indult meg. „ $A z$ új helyzetnek megfelelöen 1866 végétöl neve Országos Gazdászati Tanintézetre változott." 38

A kiegyezés közjogi aktusával a megalakuló független magyar kormányban a mezőgazdaság fejlesztése és vele párhuzamosan a szakoktatás felügyelete és irányítása a Földmívelés-, Ipar- és Kereskedelemügyi Minisztérium kezébe került. Gorove István minisztersége idején történt meg a már meglévő tanintézetek átvétele, működésük újbóli elindítása, illetve a szakoktatási hálózat kiépítése, új intézetek alapítása. ${ }^{39}$ Keszthely is, mint a többi hasonló intézmény 1874-től m. kir. gazdasági tanintézet néven vette ki részét a szakoktatásból az akadémiai rang elnyeréséig. ${ }^{40}$ A nagy múltú keszthelyi tanintézetben a tanulmányi idő két évet vett igénybe, ami 1906-ig nem módosult. A képzés színvonalának javítását a felvételi rendszer szigorításával igyekeztek elérni. ${ }^{41}$ Ennek érdekében a felvételt középiskolai végzettséghez és egyéves gyakorlathoz kötötték.

Debrecenben a mezőgazdasági szakoktatás célját és megvalósításának körülményeit illetően eltért Magyaróvártól és Keszthelytől. „A debreceni elsösorban a községtanács határozata alapján indult meg, nagyrészt saját anyagi forrásokra támaszkodva, magyar nyelvü oktatással és elsösorban a tiszántúli mezögazdaság felvirágoztatása érdekében." ${ }^{2}$ A mezőgazdasági tanintézet felállításának terve már 1856 végén megfogalmazódott a város vezetése részéről, amely egyidejűleg fontosnak tartotta mind a felső, mind az alsó

35 Uo. 30 .

${ }^{36}$ CsIKI, i. m., 35-38.

37 Uo., 43-47.

38 Emlékkönyv a Georgikon alapitásának 200. évfordulójára. I., szerk. FüLöp Éva Mária, Keszthely, 1996, 138.

39 Uo., 139.

${ }^{40}$ CsIKI, i. m., 1943. 43.

41 Uo., 44.

42135 éves a debreceni agrár-felsöoktatás, i. m., 62. 
szintủ szakoktatás megindítását. Az intézmény létesítéséhez a város nagyvonalú felajánlásokat tett, ${ }^{43}$ természetesen feltételekhez kötve. Köztük is talán a legnagyobb horderejünek tekinthető az oktatásban a magyar nyelv kizárólagos használata. Elsősorban talán ennek tulajdonítható a végleges döntés elmaradása. A város azonban nem adta föl elképzeléseit és évek múltán újabb ajánlattal lépett elö, bár ez már kevésbé tủnt olyan bőkezűnek, mint amilyen a korábbi volt. De az 1857. évi kikötésekhez ragaszkodtak. Az 1860-as évek közepén a Helytartótanács már késznek mutatkozott a végleges döntés meghozatalára, és megszületett a Debrecen polgármestere és főjegyzője által 1866-ban megfogalmazott adománylevél, amely az intézet alapítólevelének tekinthető.

Debrecen városa 400 kat. hold földet adományozott az intézmény számára, ami további 200 kat. holddal - mint bérleménnyel - egészült ki. Két helyszínen indult meg az építkezés, ${ }^{44}$ Pribik Béla felügyeletével és Glaszner Flórián vezetésével. Pallag adott otthont az 1867 nyarán megnyíló földművesiskolának, a felsőbb gazdasági tanintézet pedig a Péterfia utca végén - a mai Bem téren - lévő egyemeletes épületben, 1868 októberétől fogadta első hallgatóit. A gazdasági tanintézet az oktatásban - már megindulásától kezdve - hármas alapelvet követett, ${ }^{45} \mathrm{ami}$ az intézmény történetében is nyomon követhetö:

- a szakismeretet megalapozó alaptudományok (biológia, kémia, fizika stb.) elsajátítása;

- az agronómia egyes (szak)területeinek alapos ismerete;

- a jövedelmezőséget befolyásoló egyéb ismeretek (közgazdaság, jog, közigazgatás stb.) oktatása.

Az első igazgatót, Papi Balogh Pétert, 1869-ben Tormay Béla követte. ${ }^{46}$ Személyében tudós, egyúttal gyakorlatias szakember került az intézmény élére. ${ }^{47}$ „Kialakitotta a tanszékek rendjét, ami 1868-1906 között mindvégig megmaradt.” Deininger Imre, Békessy László, Szüts Mihály, Domokos Kálmán, Vedrődi Viktor, Bíró Pál, Réti János stb. személye utal a tanári kar felkészültségére. ${ }^{48}$ Rövid idő alatt azonban az intézmény „kinőtte” az elhelyezés kínálta lehetőségeket, ezért egy új tanintézet építésére került sor a Református Kollégium mellett, ${ }^{49}$ ahová 1883 -ban költözött át a tanintézet. De ezt csak ideiglenes megoldásnak szánták, mivel kizárólag Pallag kínált ideális helyet, ahol a tanintézet és a gazdaság együttesen elhelyezhető lett, helyet adva a tanárok szolgálati lakásainak is. Ez a pallagi épületegyüttes napjainkban már agrármúltunk fontos örökségét képezi.

\footnotetext{
43 Uo., 64.

44 Uo., 65.

45 Uo., 69.

46 Uo., 71.

47 Uo., 74.

48 Uo., 75.

49 Uo., 80.
} 
A magyar mezőgazdasági szakoktatásban a 19. század második fele az „alapítások kora”, hiszen Debrecennel nem zárult le a tanintézeti hálózat kiépítése. Erdélyben Kolozsmonostorral (1869), a Felvidéken pedig Kassával (1874) bővült számuk. Az Erdélyben létesítendő gazdasági tanintézetet különösen az Erdélyi Gazdasági Egyesület (EGE) sürgette. Helyszínéül, több lehetőséget mérlegelve, Kolozsmonostor kínálkozott a legalkalmasabbnak. ${ }^{50} \mathrm{~A}$ bérbe vett 742 kat. hold birtok egykor az I. Béla által, 1061-1063 között alapított, bencés apátsághoz tartozott, amely a tanintézet létesítése idején a katolikus püspökség kezelésében állott. Az intézmény fóépületét 1873-ban vette birtokba a hallgatóság, a konviktussal együtt. Kolozsmonostor szervezeti felépítésében eltért Keszthelytől és Debrecentől. Ezek fóbb vonásaikban a magyaróvári tanintézethez hasonlítottak. Kolozsmonostor ugyanis a bajor weyhenstephani tanintézet példáját követte, így a tanulmányi idő kezdettől fogva három évet vett igénybe. Az első év gyakorlati oktatással telt el, vagyis a felvétel követelményei között az egyéves igazolt gyakorlat nem szerepelt. Ugyanakkor hat, esetleg öt gimnáziumi vagy reáliskolai osztály elvégzése után nyert csak felvételt a jelentkező. Gondot fordítottak a tehetséggondozásra, amelyre az ösztöndíjrendszer jó alapot nyújtott. Kolozsmonostor „küldetésnyilatkozata” tükröződik Huszár Sándor miniszteri biztos véleményében. ${ }^{51}$ „A mai napon a közmüvelödésnek egy új forrása nyilik - a mai naptól kezdve új tanintézetünk van melynek hivatása célja - az ifjú nemzedéket gazdává képezni, s a már a tettleg gazdálkodóknak a haladás terén gazdasági értelmiséggel világitani."

A magyar mezőgazdasági szakoktatás utolsó fellegváraként a Kassai m. kir. Gazdasági Tanintézet ${ }^{52} 1875$-től állt a hazai agrárium rendelkezésére. Egy ideig a város riválisának számított Rimaszombat, de végül több érv szólt Kassa mellett. Az új oktatási központ szervezeti felépítése és működése az erdélyi mintát követte. Annak ellenére, hogy régi óhaj teljesült a Felvidéken, eleinte aránylag csekély érdeklődés mutatkozott iránta. Csak az FM közbelépése javított a helyzeten.

Ezekben az évtizedekben viszonylag kevés számú, jól felkészült oktató állt a mezőgazdasági tanügy szolgálatában. Ezt az FM gyakori személycserékkel igyekezett a jelentkező problémákat áthidalni. A tanár- és igazgató cserék jelentősen hozzájárultak az oktatás színvonalának javulásához, a hálózathoz tartozó intézmények színvonalbeli „egynemüsödéséhez”. Ez a gyakorlat végigkíséri az egész korszakot.

Az 1860-as évektől kibontakozó mezőgazdasági szakoktatás hazai története bővelkedett olyan reformokban, amelyekre Nyugat-Európa mutatott példát. Ezzel kapcsolatban Sporzon Pál a következőket írja: ${ }^{33}$ "A hazai gazdasági tanügy annál kevésbé maradhatott közömbös ezen reformtörekvésekkel szemközt, minthogy tudvalevö dolog,

\footnotetext{
${ }^{50}$ Magyarország mezögazdasági szakoktatási intézményei, szerk. BALÁs Árpád, Magyaróvár, 1897, 100102.

51 Vörös Sándor, A gazdasági tanügy történetének vázlata, Kolozsvár, 1880, 5.

52 Magyarország mezögazdasági szakoktatási intézményei, i. m., 109-111.

53 Sporzon, i. m., 5.
} 
hogy gazdasági tanintézeteink egészében véve régi tanrendszer mintája szerint alakultak, és másfelül olyan körülmények között létesültek, melyek a biztos és rendszeres megalapitás$r a$, valamint az egészséges és szerves kifejlödésre nem voltak kedvezök." A jövőt illetően Sporzon Pál jó érzékről tett tanúságot, amikor megállapította, hogy nem annyira az intézetek száma vagy címe az elsődleges szempont, hanem azok felszereltsége és a leendő szakemberek gyakorlatban való jártassága, ami viszont alapos elméleti tudásra épül.54 Különösen fontosnak tartotta a középfokú tanintézetek reformját, mert azok „felsőbb” elnevezésük ellenére, a gyakorlatban középfokú színvonalon oktatnak. Javasolta a hazai mezőgazdasági szakoktatásban a háromszintű képzés bevezetését:

- gyakorlati jellegü földművesiskola (bizonyos elmélet is);

- középfokú gazdasági tanintézet (több müködtetése az elmélet-gyakorlat egységére épülve);

- gazdasági akadémia (legfeljebb egy az országban, a tudományos elméleti oktatás elsőbbségére alapozva).

Az első átfogó reform során nemcsak az egyes iskolatípusokkal szemben támasztott követelményeket fogalmazták meg, hanem besorolták a már meglévő intézményeket is. 1874-től felsőfokú intézetként mủködött tovább az akadémiai rangra emelt Magyaróvár, ahol a legjobb tanerőket vonták össze az egyes tanintézetekből. A képzési idő két esztendő maradt. A felvételt középiskolai végzettséghez és egy év előgyakorlathoz kötötték. A megszerzett oklevél gazdatiszti állás betöltésére jogosította föl a végzett hallgatót.

A középfokú intézetek közé sorolták be Debrecent, Kassát, Keszthelyt és Kolozsmonostort, melyek egységesen m. kir. gazdasági tanintézet megnevezést kaptak. Az egyes intézményeknél a korábban is meglévő felvételi követelmények nem változtak. (Hat középiskolai osztály elvégzése, egyéves előgyakorlat, kétéves képzés, illetve hat középiskolai osztály elvégzése és előgyakorlat nélkül hároméves képzés). A megszerzett oklevél jellegű végbizonyítvány szintén feljogosította a végzett hallgatót gazdatiszti állás betöltésére.

Az alsó fokú szakoktatás az elemi iskolára épült, kétéves képzéssel, s gazdasági altiszti (majoros és béresgazda) munkakörök betöltésére nyújtott lehetőséget.

A felső- és középfokú szakoktatás rendszere 1906-ig alapvetően nem változott. Szembetűnő viszont a fejlődés az alsó fokú képzés terén. (Ez mai értelemben vett szakmunkásképzés volt.) A földművesiskolák mellett a mezőgazdaság más ágazataiban (kertészet, erdészet) is felgyorsult az iskolaalapítás üteme. ${ }^{55} \mathrm{~A}$ keszthelyi tanintézet újraindulásával egyidejűleg megnyílt a fölművesiskola is, és egy évtizedig (1865-1875) működött. Hasonló volt a helyzet Debrecenben is, ahol 1867-1899 között létezett ilyen intézmény. De a két példa nem tekinthető általánosnak.

\footnotetext{
${ }^{54}$ Heckenast-Zsinka, Szakoktatástörténet I., i. m., 31-33.

55 CsIKI, i. m., 51.
} 
Bár az Országos Magyar Gazdasági Egyesület a hazai szakképzés általános fejlesztéséért szállt síkra, végső soron azonban az agrároktatás elsősorban a nagy- és középbirtok érdekeit szolgálta. Ez nem kérdőjelezi meg az alsó fokú szakoktatás fejlődésének eredményeit. A Felvidéken az első földművesiskola 1871-ben Liptóújváron létesült, ${ }^{56}$ ahol az oktatás részben szlovák nyelven folyt. Az intézmény rövidesen átkerült Rimaszombatra (1884). 1875-ben ${ }^{57}$ az OMGE kezdeményezésére nyitotta meg kapuit az István-telki intézet, amely azonban 1891-ben megszűnt. ${ }^{58}$ Helyén kertészképző létesült. Esterházy Miklós Móric magánalapítású földművesiskolája 1891-ben kezdte meg tevékenységét Csákvárott. Darányi Ignác minisztersége idején teljesedett ki az állami fenntartású alsó fokú szakképző hálózat:59 Zsitvaújfalu (1883-1895), Ada (1884), Csákóvár, Szentimre (1886), Algyógy (1892), Pápa (1893), Kecskemét, Lúgos (1895), Jászberény, Hódmezővásárhely, Békéscsaba (1896), Szabadka, Komárom (1898), Karcag (a debreceni helyett - 1899), Breznóbánya (1901), Szilágysomlyó (1902), Csíkszereda (1904), Nagykálló (1911), Kisszeben (1912), Árvaváralja (szlovák nyelvű) és Torda. Az erdélyi szászok saját elhatározásból indították meg a német nyelvü alsó fokú szakoktatást: Beszterce (1870), Földvár (1871), Medgyes (1871 - gazdasági tanintézet). 1888-ban a német nyelvü intézmények száma bővült a nagyszebeni gazdasági cselédképző iskolával.

Az első világháborút megelőzően húsz állami, egy magán alapítású és három egyesületi (szász) földművesiskola működött. Noha az utóbbiakban az oktatás német nyelven folyt, a magyar nyelv tanítása kötelező volt. A 78.516/1898. sz. FM rendelet ${ }^{60}$ életre $^{2}$ hívta a földművesiskolák keretén belül a téli gazdasági iskolákat, ahol a gazdák tanfolyamokon ismerkedhettek a mezőgazdasági termelés időszerü kérdéseivel.

Az 1868. évi XXXVIII. tc. (népoktatási törvény) ${ }^{61}$ lehetőséget teremtett arra, hogy a közoktatás keretében a tantervbe bekerüljön a mezőgazdasági ismeretek oktatása is. Az ún. ismétlő-iskola látogatását a 12-15 éves gyermekek számára kötelezővé tették három éven keresztül. A 60.764/1896. VKM sz. rendelet pedig életre hívta a gazdasági ismétlőiskolákat, és egyértelműen előírta a tanköteles korú fiatalok számára az alapfokú szakismeretek oktatását. Az 1902. évi 66.569. sz. VKM rendelet ${ }^{62}$ gyorsította a gazdasági ismétlőiskolák, különösen a szak-tanítós ismétlőiskolák létesítésének az ütemét. Ez utóbbival kapcsolatban megjegyzendő, hogy 1910-ben Komáromban gazdasági tanító, Kecskeméten pedig gazdasági tanítónői intézet nyílt meg az FM égisze alatt. ${ }^{63}$ Mindkét

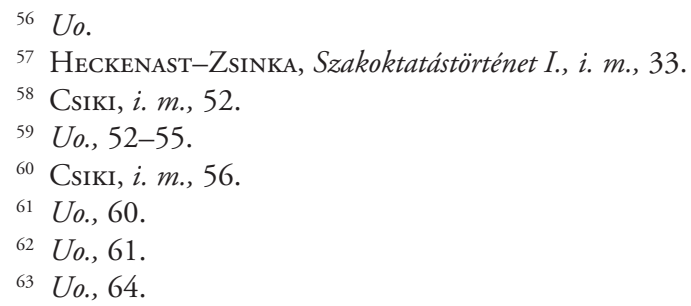


intézet szoros kapcsolatot tartott a helybeli földműves-iskolával. ${ }^{64}$ Ezenfelül több más magán és állami fenntartású szakképző intézet, tanfolyam is működött az országban, közülük jó néhány háziasszonyok számára adott hasznosítható gyakorlati ismeretet. ${ }^{65}$

A 72.445/1 V. A. 1. FM rendelet a „[...] magyaróvári akadémia szervezeti és oktatási színvonalára emelte a korábban középfokúként müködö agrárintézeteket [...] a debreceni tanintézet átszervezéséröl is intézkedett, $s$ a kolozsvárival, kassaival, keszthelyivel együttesen azt akadémiai rangra emelte." ${ }^{\prime 6}$ Amint korábban már említettük, a gazdatiszti képzést vállaló tanintézetekben eltérő színvonalú oktatás folyt, ami egyúttal különböző tanrendet, tanulmányi szabályzat alkalmazását is jelentette. Ezt kívánta orvosolni a 22.924/1889. FM sz. rendelet, amely egységes tanulmányi szabályzatot vezetett be. Az 1906-ban adományozott akadémiai rang azt is jelentette, hogy az általános mezőgazdasági képzésből „eltűnt” a középfokú tagozat ${ }^{67} \mathrm{E}$ probléma megoldására csak a két világháború közötti években került sor.

A hazai agrárium szempontjából fontos mozzanat volt az önálló Földművelésügyi Minisztérium létrehozása, az 1889. XVIII. tc. értelmében, ${ }^{68}$ melynek teljes szervezeti kiépülése az első világháborút megelőző években fejeződött be. Erre az időszakra esik Darányi Ignác (1849-1927) két ciklusra terjedő minisztersége (1895-1903, 1906-1910), amely alatt számos fontos törvény született meg. „Politikusi pályája kezdetétól sokat tett a mezögazdaság szinvonalának emeléséert. Megoldást keresett a társadalomban felhalmozódó szociális gondok enyhitésére és nagy figyelmet szentelt a kiszolgáltatott helyzetben lévo", önmaguk megsegitésére képtelen mezögazdasági alkalmazottak, a kisemberek problémáinak kezelésére. "69 De ugyanígy szívügyének tekintette a mezőgazdasági szakoktatás és kísérletügy fejlesztését is, ami egyúttal hatékonyságának javulását is jelentette. Felismerte, hogy „[...] az ésszerübb gazdálkodás útján haladó nagybirtok gazdatiszti szükséglete elötérbe állitotta a gazdasági tanintézetek eddigi képzési rendszerének megváltoztatását, a tanulmányi idö felemelését, a tantárgyak elmélyültebb oktatását. Ismét napirendre került a felsöfokú mezögazdasági képzés fejlesztése, saz agrároktatás egyetemi követelménye az egész ország szakembereit mind eröteljesebben foglalkoztatta. "70

Amint korábban már említettük, a mezőgazdasági szakoktatás igyekezett lépést tartani a hazai agrárium szerkezetének változásával, a termelés színvonalának javulásával. $\mathrm{Az}$ állattenyésztésben, ezen belül is a szarvasmarha-ágazatban bekövetkező fajtaváltás nagyban hozzájárult a tejgazdaság fejlődéséhez. Vele párhuzamosan megnőtt az igény a tejgazdasági szakismeret iránt. ${ }^{71} 1886$-ig a hallgatók kizárólag a gazdasági taninté-

${ }^{64}$ Uo., 65.

${ }^{65}$ Uo., 65-66.

${ }_{66}$ Uo., 57.

${ }^{67}$ A földmüvelésügyi szakigazgatás története 1867-1948, i. m., 88.

${ }_{68}$ A folldmüvelésügyi szakigazgatás története 1867-1948, i. m., 78-81.

${ }^{69}$ Darányi Ignác. Válogatott dokumentumok, szerk. FeHÉr György, Budapest, 1999, 24.

${ }^{70}$ A debreceni agrár-felsöoktatás 100 éve, szerk. Komoróczy György, Budapest, 1968, 57.

${ }^{71}$ CsıкI, i. m., 57. 
zetekben és a földművesiskolákban szerezhettek jártasságot a tejgazdálkodás köréből. Az iránta megnyilvánuló érdeklődés kielégítésére a tanfolyamok szervezése kevésnek bizonyult, amivel az FM is tisztában volt. A probléma megoldására biztosítékot a szakképzés megszervezése jelentett. Az első tejgazdasági szakiskola Láncpusztán (Sárvár) létesült 1890-ben, amely 1929-ben átkerült Csermajorba. ${ }^{72}$ A 19. század utolsó évtizedében az ország számos pontján nyílt meg tej-munkásképző szakiskola: Munkács, Gödöllő, Nagyszécsény, Kisbér, Csákóvár, Szabadka. ${ }^{73}$

A 19. század végén a mezőgazdaság más ágazataiban is változott a szakképzés jellege. ${ }^{74}$ A kertészeti szakoktatás megújulását szolgálta az 1885-ben megalakult Országos Magyar Kertészeti Egyesület ${ }^{75}$ törekvése, amely találkozott az OMGE szándékával. Rudinai Molnár István nevéhez füződik a felsőfokú kertészeti tanintézet felállítása, amely szervezeti felépítésében és szabályzatában francia mintát követett. 1894 végén nyílt meg a Magyar kir. Kertészeti Tanintézet. Megjegyzendő, hogy Entz Ferenc, R. Molnár István és Angyal Dezső nemcsak a modern magyar kertművelés, hanem a hazai szakképzés megteremtője is. Szerepük messze túlmutatott az ország határain. Tevékenységükkel nagymértékben hozzájárultak ahhoz, hogy a kertészeti szakoktatás a magyar agrárképzés egyik legsikeresebb területévé váljon a 20. század első felében. De nem kisebb az érdemük abban sem, hogy lerakták a nemzetközileg is elismert magyar kertészeti kutatás alapjait.

A kertészet iránt megnyilvánuló hazai érdeklődést jelzi, hogy erre az időszakra esett

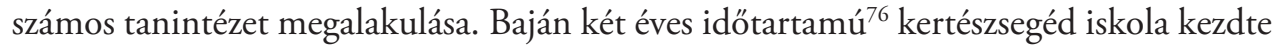
meg működését. A szőlészeti és borászati szakoktatást 1892-ben a fóvárosban induló Felsőbb Szőlő- és Borgazdasági Tanfolyam, 1901-től a budafoki pincemesteri tanfolyam, továbbá négy középfokú és négy alsófokú vincellériskola látta el.

A Bányászati és Erdészeti Főiskola (Selmecbánya) erdészeti tagozata, valamint négy erdőőri (alsófokú) szakiskola biztosította a hazai erdőművelésben a szakember-utánpótlást.

Az állatorvoslás terén is jelentős elörelépés történt. 1890-ben már négyéves akadémiát végeztek a gyógyítás szakemberei, amit 1899-ben a föiskolai státusz követett (13.345/1899. FM sz. r.). A továbbképzést a rendszeres tanfolyamok biztosították. A méhészeti oktatásnak Gödöllő adott otthont.

A szakemberképzés, a kutatói utánpótlás eleinte szorosan kötődött a mezőgazdasági szakoktatási intézetekhez. 1871 határkő a hazai mezőgazdasági kísérletügy történetében. ${ }^{77}$ „[...] több oldalról élénk óhajtás nyilvánult a gazdasági kisérleti állomások felálli-

72 Uo., 58.

73 Uo., 59.

${ }^{74}$ Uo.

75 SuRÁNYi Béla, A magyar kertészeti szakoktatás vázlata, Debrecen, 2001. (Kézirat)

${ }^{76}$ A földmüvelésügyi szakigazgatás története 1867-1948, i. m., 88.

77 FeнÉr György, A mezögazdasági kísérletügy kialakulása Magyarországon (1869-1914), Budapest, 1982, 15-16. 
tása iránt... [Megoldásnak tekinthető, ha] ... a gazdasági kisérleti állomások egyelöre a gazdasági tanintézetekkel egybekötve állittattatnak fel [...]." Megállapodás született abban is, hogy Debrecenben és Magyaróváron kerüljön erre egyelöre sor. 1869-ben Magyaróvárott létesült az első kísérleti intézet Gazdasági Eszköz- és Gépkísérleti Állomás néven. ${ }^{78} \mathrm{~A}$ kísérletügy gerincét a vegykísérleti állomások alkották, amelyből az elsőt 1872-ben szintén Magyaróvár szervezte meg. ${ }^{79}$ A Debreceni Vegykísérleti Állomás ${ }^{80}$ bizonyos értelemben megelőzte az óvárit, mivel Vedrődy Viktor már 1869-től magánjellegű intézetként mủködtette. Keszthelyen ${ }^{81} 1884$-benk kezdődött el a munka, Kassával egyetemben. Legkésőbb a kolozsvári állomás alakult meg 1889-ben, s müködésében nagy szerepet játszott a Ferenc József Tudományegyetem. ${ }^{82}$

A hazai kísérletügy másik csoportját képezték a vetőmagvizsgáló állomások. ${ }^{83} \mathrm{Az}$ első színhely Magyaróvár, ahol a Debrecenből átkerülő (1878) Deininger Imre vezetésével indult meg a munka. Ezt követte 1884-ben Debrecen, Kassa, Keszthely és Kolozsvár. ${ }^{84}$

A M. kir. Dohánytermelési Kísérleti Állomás Debrecenhez kötődik, felállítására 1898-ban került sor. ${ }^{85}$ Az irányításával Kerpely Kálmánt, az MTA levelező tagját bízták meg. ${ }^{86} \mathrm{Az}$ intézet „[...] munkájával európai hírnévre tett szert, jóllehet itt - Kerpely Kálmán kivételével - nem dolgoztak olyan képességü szakemberek, akikböl a Magyaróvári Növénytermelési Kisérleti Állomáson többet is találtunk. "87 A teljesség igénye nélkül, mindenképpen említeni kell a Magyaróvárott létesített Növénytermelési Kísérleti Állomást, amelyet olyan szakember indított útjára, mint Cserháti Sándor. ${ }^{88}$ Szerepét mi sem jelzi jobban, mint az, hogy amikor 1909-ben Budapesten létrehoztak egy hasonló intézményt, rövid idő után (1910-ben) áthelyezték Magyaróvárra, a növénytermelési kísérletügy vidéki fellegvárába, s vezetését Cserháti Sándorra bízták. ${ }^{89}$

Az 1890-es évektől kezdett különválni a hazai mezőgazdasági kutatás a szakoktatási intézetektől, Debrecentől és Magyaróvártól eltekintve. Az FM szervezésében és felügyelete alatt egymás után alakultak meg az országos hatáskörű kutatóintézetek, amelyek hosszú időn keresztül meghatározták a mezőgazdasági kutatások színvonalát. ${ }^{90}$ Létrejött a Mezőgazdasági Kísérletügyi Tanács, melynek szakfolyóirata a Kísérletügyi

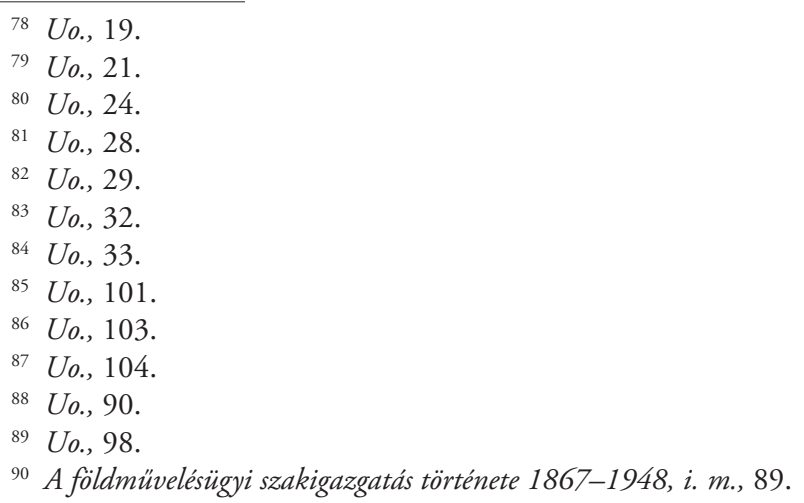


Közlemények már 1898-ban útjára indult. A 20. század első évtizedeiben a magyar mezőgazdasági kutatást, intézményi hálózatát, a bennük folyó munkát, a világon a negyedik legjelesebbként tartották számon, s ebben nagy szerepe volt a Földművelésügyi Minisztérium Kísérletügyi Osztályának.

\section{A magyar mezögazdaság általános helyzete 1920 után}

$A z$ első világháború után megváltozott Európa politikai, gazdasági képe. ${ }^{91}$ A szerves fejlődés eredményeként a Kárpát-medencében kialakult gazdasági kapcsolatokat a párizsi békerendszer szétzilálta. A politikai döntés talán legnagyobb vesztese Magyarország lett, amely területének $67 \%$-át, benne jelentős mezőgazdasági területtel, elveszítette. ${ }^{92}$ Mindez azt eredményezte, hogy nemcsak a monarchia egyes országai között, a korábbi évtizedekben kialakult munkamegosztás szünt meg, hanem a Kárpát-medence egyes tájai közötti is. „Az új országterületen a mezögazdaság szerkezetének különbsége nem tekinthetö önmagában hátrányosnak, a változások összességükben mégis kedvezötlenebb helyzetet jelentettek mezögazdaságunk számára, mint a ko.rábbi helyzet volt." ${ }^{33} \mathrm{Ez}$ lemérhető az egyoldalú gabonatermesztés arányának valamint nagybirtok súlyának növekedésében is. A megrekedt gazdasági-társadalmi rendszer nehezítette, illetve megakadályozta egy hosszú távú agrárpolitika kibontakozását, így a termelés modernizációját. Mindezt tetézte a nemzetközi konjunktúra megtorpanása, a gazdasági világválság. Közgazdasági dogmává merevedett a viszonylag jövedelmező nagybirtok védelme. Mivel elmaradt az alapprobléma megoldása, a földosztás és vele párhuzamosan az iparfejlesztés is, így érintetlen maradt az ország agrárszerkezete, $s$ elodázódott az átfogó reform, amelyekhez hiányzott a politikai akarat. A Nagyatádi féle földreform (1920. évi XXXVI tc.) csak egy bátortalan kísérletként vonult be a magyar agrártörténetbe. ${ }^{94}$

Az 1930-as évek második felében mutatkozó némi javulás az állami beavatkozásnak és a háborús konjunktúra kibontakozásának volt köszönhető, ${ }^{95}$ aminek következtében növekedett a munkaigényes növénykultúrák vetésterülete, hozzá hasonlóan az olajos növényeké is. ${ }^{96} \mathrm{~A}$ zöldségtermesztés, gyümölcsészet, továbbá a bortermelés is nagy ívű fejlődési pályát futott be. ${ }^{97}$ Ezen eredményekben alapvető szerepet játszott, hogy a növény- és állatnemesítés állami kézbe került. 1929 után állami támogatással mind szélesebb körben terjedt a parasztság gazdálkodásában is a nemesített vetőmag használata, a hazai nemesítő telepeken folyó munka eredményeként. Lépések történtek annak érde-

\footnotetext{
${ }_{91}$ A magyar mezögazdaság 1000 éve, i. m., 89-90.

92 Gunst Péter, Mezögazdasági termelés története Magyarországon (1920-1938), Budapest, 1970, 30-60.

${ }_{93}$ Uo., 60.

94 A magyar mezögazdaság 1000 éve, i. m., 92.

${ }_{95}$ Uo., 96-97.

96 Uo., 100.

${ }^{97}$ Uo., 101.
} 
kében is, hogy a tájtermesztést tudományos alapokra helyezzék, és erre újabb alkalmas körzeteket vonjanak be az ország területén. ${ }^{98}$

Az állattenyésztés talán jobban megsínylette az 1920 után végbemenő változásokat, mint a növénytermesztés. ${ }^{99}$ Ugyanakkor a szarvasmarha-tenyésztés ezekben az évtizedekben vált a magyar mezőgazdaság meghatározó ágazatává, ami elválaszthatatlanul összeforrt a magas színvonalú állatorvoslással, állategészségüggyel. A sertéstartás terén is szembetünő javulás volt tapasztalható, bár a javított változatú mangalicafajta uralta továbbra is a mezőnyt. Az évszázados juhfajták azonban visszaszorultak, átadva helyüket a kor igényeihez idomuló fajtáknak. A stagnáló lóállomány (fajta arány) a gépesítés üteméről mondott kritikát. A tudományos alapokon nyugvó nemesítési eljárások térhódítása javította a magyar állattartás minőségi színvonalát, jóllehet az állatállomány létszáma a lakosság számához viszonyítva csökkent.

\section{A hazai oktatásügy 1920-1944 között}

A „trianoni sokk” által kiváltott nemzeti bezárkózás első megnyilvánulása a hírhedt 1920. évi XXV. tc. (numerus clausus) elfogadása, amely a felsőoktatásra vonatkozott. ${ }^{100}$ Önkéntelenül is felvetődhet a kérdés, hogy a korabeli oktatáspolitika, ezen belül a mezőgazdasági szakoktatás mennyiben felelt meg az akkori politikai, gazdasági helyzetnek, lépést tartott-e vele, képes volt-e követni a változásokat. Az összkép lényegében ellentmondásos.

A Bethlen-kormányban a Vallás- és Közoktatásügyi Minisztérium élére Klebelsberg Kunó (1875-1932) került. 1922-1931 között állt a tárca élén, s kultúrpolitikája nagyban elősegítette az 1920-as évek konszolidációját: „[...] egyrészt a Trianon sokkjából még fel sem ocsúdó magyar társadalom szellemi népgyógyításának eszköze lett, másrészt pedig a magyar társadalom belsö szerkezetének lassú evolúcióját, konzervativ modernizációját segitette elo". "101 Mindezt egyfajta „tudásberuházással” kívánta elérni. Az oktatás fejlesztése, a szellemi beruházás ösztönzése Klebelsberg szerint azt jelentette, hogy "[...] a kultúrtárca egyben honvédelmi tárca is" ${ }^{102}$ ami lényegében a vesztett háború következményeinek szellemi korrekcióját kívánta végrehajtani, s az ún. kultúrfölény megteremtésével szándékozott az országot a területi revízióra előkészíteni. A „nemzeti mint fogalom" túlhangsúlyozása csak akkor nyerhetett értelmet, ha ez a kultúrpolitika "népbarát”. Ezért „[...] Klebelsberg kultúrpolitikájában [...] nagy hangsúlyt kaptak a nép müvelödését szolgáló, a népoktatást fejlesztö intézkedések." 103

\footnotetext{
${ }^{98}$ Magyary Zoltán-Reichenbach Béla, A szántófóldi termesztés és állattenyésztés üzemi tájai. Magyarország mezögazdasági politikájának alapvetése I. Budapest, 1941.

${ }^{99}$ A magyar mezögazdaság 1000 éve, i. m., 103-106.

100 MészÁros-Németh-Pukánszky, i. m., 2003, 320.

101 Uo.

102 Uo.

103 Uo., 321.
} 
A népoktatás prioritása érvényesült a közoktatás és a szakképzés terén is. 1926-ban törvényt hoztak a mezőgazdasági népesség érdekeit szolgáló népiskolák létesítéséről és fenntartásáról (1926. évi VII. tc.). ${ }^{104}$ Csak az 1929-1931-es gazdasági világválság hiúsította meg a nyolcosztályos népiskola tervét. Már 1927-ben program indult az iskolán kívüli népművelés fejlesztésére, amely azonban csak az 1930-as években teljesedett ki gazdatanfolyamok, iparoskörök formájában. A klebelsbergi kultúrprogram komoly szerepet szánt a polgári iskoláknak is, ${ }^{105}$ amelyeket az 1927 . évi XII. tc. középfokú iskolává minősített. (A népiskola 4. osztályának elvégzése után ebben az iskolatípusban folytatták tanulmányaikat a tízéves kort elért tanulók.) 1928 őszén Polgári Iskolai Tanárképző nyílt Szegeden a megfelelő létszámú tanerő biztosítására.

Változott a középiskolai képzés is. ${ }^{106} \mathrm{Az} 1924$. évi reform ${ }^{107}$ három középiskola-típust különböztetett meg: gimnázium, reálgimnázium, reáliskola.

A törvény kibocsátásával megszűnt a gimnázium megkülönböztetett jellege, $s$ mindhárom iskolatípus egyenlő esélyt teremtett maturanduszainak tanulmányaik folytatására. A leányok középiskolai képzéséről - ami magába foglalta a leánygimnáziumot, a leánylíceumot és a leánykollégiumot -, az 1926. évi XXIV. tc. rendelkezett. ${ }^{108}$

Elnevezésével ellentétben középfokú szakiskolaként működött a felső kereskedelmi iskola, a felső ipari iskola és a felső mezőgazdasági iskola (később részletezve).

A felsőoktatás gerincét a tudományegyetemek alkották, Budapest, Debrecen, Szeged és Pécs székhellyel. A M. kir. József Nádor Műszaki és Gazdaságtudományi Egyetem ${ }^{109}$ integráció eredményeként született meg a következő karokkal:

- mérnöki és építészmérnöki;

- gépész- és vegyészmérnöki;

- bánya-, kohó- és erdőmérnöki;

- mezőgazdasági és állatorvosi;

- közgazdaságtudományi.

A főiskolai hálózathoz tartoztak a hittudományi föiskolák, jogakadémiák, tanárképző főiskolák, gazdasági akadémiák, a kereskedelmi föiskola, művészeti (képző-, zene) föiskolák, a tisztképző főiskola és az 1925-ben nyíló Magyar Testnevelési Főiskola. 1924-ben született meg a törvény a középiskolai tanárok képzéséről és képesítéséről. Ezekben az években alakították ki a gyakorló középiskolák hálózatát.

Hóman Bálint (1885-1953) 1932-1942 között vezette a vallás- és közoktatási tárcát. ${ }^{110}$ Müködése alatt indult meg a nyolcosztályos népiskola kialakításának folyamata. Az 1934. évi középiskolai reform (1934. évi XI. tc.) újból a gimnáziumok számára adta

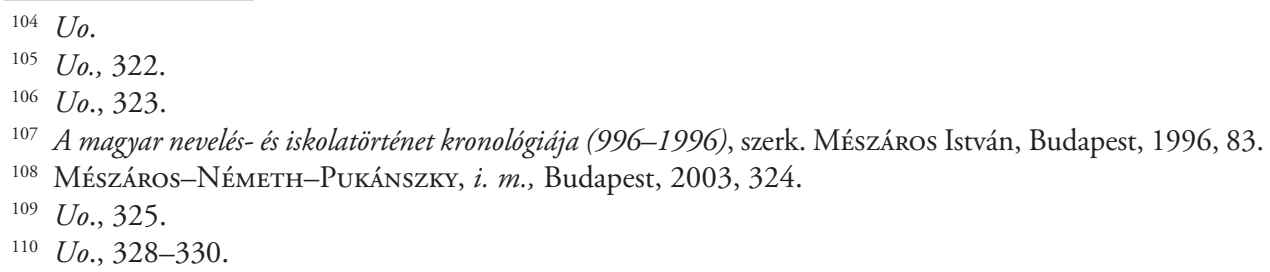


át az elsődleges szerepet, mivel megszüntette a reálgimnáziumot és a reáliskolát, vagyis az egységes középiskolát a gimnázium képviselte. Működése alatt jött létre a közoktatás egységes felügyeleti szervezete, s ennek kapcsán megszűnt a népiskolai tanfelügyelöségek önállósága. Továbbra is érvényesült az egyházi fenntartású iskolák felett az állam felügyeleti joga.

\section{Elképzelések a mezögazdasági szakoktatásról a két világháború között}

1920 után a politikai határok változása miatt csorbult Magyarországon a mezőgazdasági szakemberképzés oktatási hálózata is. ${ }^{111}$ Érzékeny veszteséget okozott a felsőoktatásban Kolozsvár és Kassa kiesése. A határ túlsó oldalára került a komáromi szaktanítónő-képző intézet is. Mindez jó néhány földművesiskolára is vonatkozott. Az új államalakulatokban korábban a magyar állam érdekeit szolgáló mezőgazdasági intézményeknek a jövője bizonytalanná vált, különösen a határ túlsó oldalára került magyar etnikum számára. Mindezt tetézte az, hogy az 1920 utáni korszak számos olyan problémát, megoldatlan feladatot örökölt, mely még az Osztrák-Magyar Monarchia idején halmozódott föl.

Amint korábban említettük, a mezőgazdasági szakoktatás 1918 előtt a nagy- és középbirtok szolgálatában állott, amit igazol a felsőfokú intézetek hallgatói létszámának magas aránya a földművesiskolák tanulóihoz képest. Az agrárökonómia az alkalmazott természettudományi ismeretekkel szemben alárendelt szerepet játszott. Aránytalanság volt tapasztalható a költségvetés terén is, hiszen pl. 1913-ban a szakoktatásra fordított összeg 11,3 millió koronára rúgott, ebből a mezőgazdasági oktatásra csak 4,2 millió korona jutott. ${ }^{12} \mathrm{Az} 1920$ utáni évtizedekre várt a középfokú oktatás megszervezése, az alsó fokú képzés kiszélesitése, formáinak bővítése és a gazdasági tanárképzés helyzetének megoldása, valamint az intézményi hálózathoz kötődő, de a szervezett oktatás keretein kívüli ismeretterjesztés feltételeinek a megteremtése, továbbá az iskolán kívüli tanfolyamok rendszerének kiépítése.

A két világháború között állandóan napirenden volt a mezőgazdasági egyetem kérdése, ${ }^{113}$ annak ellenére, hogy már az 1920. évi XXX tc. intézkedett a Kir. Magyar Tudományegyetem mellett működő Kir. Magyar Közgazdaságtudománvi Kar felállításáról, ${ }^{114}$ melynek keretében mezőgazdasági szakcsoport is működött. Az 1934. évi X tc. által életre hívott M. kir. József Nádor Műszaki és Közgazdaságtudományi Egyetem ${ }^{115}$ Mezőgazdasági és Állatorvosi Karáról szóló törvényjavaslat tárgyalása során felszólalt

\footnotetext{
111 CsIKI, i.m., 66-67.

112 A földmüvelésügyi szakigazgatás története 1867-1948, i. m., 88.

113 Buday B., A gazdasági szakoktatás megszervezése, Köztelek (1932/9-10), 76.

114 CsIKI, i.m., 67.

115 Uo., 68-69.
} 
Somssich László, ${ }^{116}$ támogatván - ha nem is önálló egyetemként, de kari tagozódásban - a mezőgazdaságtan egyetemi oktatását. Ugyanakkor ellenezte azt a debreceni kezdeményezést, amely a közgazdasági kar mezőgazdasági szakának Debrecenbe történő áthelyezését szorgalmazta. Ennek nyomán a Pallagon levő gazdasági akadémia megszűnt volna, és egyetemi szakként működött volna tovább, oktatási célokra felhasználva a tangazdaságot is. Ezt a tervet annak idején támogatta Bethlen István miniszterelnök is. ${ }^{117}$ Véleménye szerint: „[... ] ha van az országban egy pont, ahol a mezögazdasági tudományokat a legfelsö fokon lehet müvelni, akkor az Debrecen." "118 Ez a megoldás a Debreceni Gazdasági Akadémia és a Tisza István Tudományegyetem integrációjából valósult volna meg. Bethlen egyúttal támogatta a középfokú gazdasági tanintézet létesítését is. A debreceni tervet ejtették, de a Bethlen-kormány bukása után a Károlyi-kormány újból elővette, noha az OMGE által kibocsájtott memorandum legfóbb érvként az új intézménnyel szemben a fôváros tudományos intézményhálózatának elvesztését és a vidéki gazdaképző bázis gyengülését hozta föl. ${ }^{119} \mathrm{Az}$ OMGE-vélemény mögött a nagybirtok ellenérdekeltségét lehet felfedezni. Azt sem szabad elfelejteni, hogy már akkoriban is, még ha csak látensen is, de létezett a főváros és vidék érdekellentéte.

Az 1934-ben megnyílt József Nádor Müszaki és Gazdaságtudományi Egyetem feletti felügyelet kérdése is heves vitát váltott ki a gazdatársadalom körében. „Ez $a z$ új egyetem ugyan nem a mi eszménket valósitotta meg, mert a gazdatársadalom régi és mindvégig kitartott kivánsága az önálló mezögazdasági egyetem volt. "120 (Az agrárium 1945-ben kapott önálló egyetemet.) A szakemberek elfogadták ugyan a köztes megoldást, de ezt csak átmeneti állapotnak tekintették. A hatáskör kérdése újból felborzolta a kedélyeket, mivel a Hóman Bálint vezette VKM a gazdasági szakoktatás egész hálózatát szerette volna hatáskörébe vonni. A „hatásköri” vita a VKM és az FM között változó intenzitással folyt, aminek eredménye az lett, hogy az egyetemi szintű mezőgazdasági oktatás, a gazdasági tanárképzés és néhány középfokú mezőgazdasági jellegű tanintézet véglegesen a kultusztárca felügyelete alatt maradt. A mezőgazdasági szakoktatás gerincét adó intézetek azonban továbbra is a Földművelésügyi Minisztérium felügyelete alatt maradtak.

A magyar mezőgazdasági szakoktatás korszerűsítése, az előző korszakból örökölt hiányosságok felszámolása beleillett abba a reformvonulatba, amely végigkíséri a két világháború közötti évtizedek hazai oktatáspolitikáját. A szakoktatás modernizációját és az iskolahálózat bővítését együtt kellett végrehajtani. A Trianon utáni területvesztés felértékelte az oktatás jelentőségét és a paraszti gazdálkodás szerepét. Gazdasági súlyához képest azonban az Alföld agrároktatása - intézmények száma, oktatás színvonala - kevésbe tükrözte az országos helyzetet, így e terén is elmaradott területnek számított.

\footnotetext{
116 A mezögazdasági egyetemért: Sommsich László gróf beszéde a Felsőházban, Köztelek (1934/37-38), 361-362.

117 Bethlen István gróf Debrecennek igéri a mezögazdasági egyetemet, Köztelek (1932/45-46), 419.

118 Uo.

119 A debreceni terv ellen, Köztelek (1931/29-30), 451.

120 Gazdát cserél a gazdasági szakoktatás? Köztelek (1934/83-84), 753.
} 
Schandl Károly (1882-1972), a korszak egyik jelentős agrárpolitikusa, ${ }^{121}$ az 1920-as évek végén irányelveket dolgozott ki a gazdasági szakoktatás fejlesztésére: „Hogy a mezögazdasági kultuira színvonalának emelésére és általánositására irányuló munka, a gazdasági szakoktatás mennyire elsörangú tényezöje a termelés fejlesztésének, azt legélénkebben mutatja az a körülmény, hogy a gazdasági szakoktatást az összes agrárállamok feltünö sietséggel és nagyarányú áldozatokkal iparkodnak megszervezni és kiépiteni. "Véleménye szerint az agronómia tudományának művelése nélkül sem tanárképzésről, sem a tudomány haladásával lépést tartó szakoktatásról nem lehet beszélni. A mezőgazdasági kutatás és a gazdasági szakoktatás számos ponton érintkezik, amit nem lehet figyelmen kívül hagyni. „[A] szakoktatás, mely nélkülözi a tudományos búvárkodás támogatását, hátra marad. A kisérletezés, mely nem tudja hasznositani megállapitásait az oktatás útján, elveszti gyakorlati értékét." 122

Az agrár-felsőoktatás jövőjét illetően Schandl nehezményezte, hogy a felsőfokú oktatást reprezentáló intézetek valójában „csak” gyakorlati képzést folytattak. Szorgalmazta a tanulmányi rend reformját, amelyben helyet kap a talajtan, az agrokémia, az élettan, az örökléstan és üzemtan, csak úgy, mint a kereskedelmi ismeretek és a műszaki tudományok. Az elméleti tárgyaknak a „gyakorlati szembesitése” elkerülhetetlen. Síkra szállt a négyéves képzés mellett. Továbbá hangsúlyt helyezett a szakosodásra is, sőt bizonyos integrációt - amennyiben lehetséges - sem tartott kizártnak. Például a magyaróvári akadémia szorosabb együttműködését szorgalmazta az állatorvosi föiskolával és Sopronnal. Debrecen esetén az alföldi gazdálkodás sajátosságaira is komoly súlyt kívánt helyezni, „[...] a keszthelyi a mai tananyag mellett szölészeti és kertészeti feladatát is ellátná.” Vagyis a táji adottságokra ügyelve bővíteni szerette volna a felsőfokú agrároktatás oktatási szerkezetét, bizonyos egyéni arculatot kölcsönözve neki.

A középfokú oktatás - a korabeli agrároktatás leggyengébb láncszeme - „lemaradása” az akadémiák létrehozásának a következménye volt. A fejlesztési elképzelések inkább egy befejezett képzést nyújtó iskolatípusban látták a magyar mezőgazdaság érdekeit, nem pedig olyanban, amely szinte kizárólag a továbbtanulás esélyeit teremtette volna meg a tanulók számára. Ezt a szakoktatást középiskolára vagy polgári iskolára kívánták építeni, három vagy négyévi képzéssel. A tananyag gerincét a gazdasági szakismeretekre helyezték, amit közismereti tárgyak oktatása egészített volna ki. Gondolván itt főleg az állampolgári és közgazdasági ismeretekre. A végbizonyítvány a középiskolai érettségivel közel azonos kedvezményeket szándékozott volna nyújtani a végzős növendékeknek. A középfokú mezőgazdasági szakképzésnek ilyen irányú fejlesztését Buday Barna (az OMGE igazgatója) dolgozta ki.

Az alsó fokú szakoktatást a mezőgazdasági szakiskola, a korábbi földműves-iskola, testesítette meg. Schandl Károly ezt tartotta a legsürgetőbb feladatnak. 1918 előtt 19

${ }_{121}$ Magyar Életrajzi Lexikon III., szerk. KenYeres Ágnes, Budapest, 1981, 680-681.

122 Irodalmi szemelvények és magyarázatok a mezögazdasági szakoktatás-történethez II., szerk. HeCKENAST József, Gödöllö, 1987, 497-503. 
intézmény működött az országban, alig kétszáz növendékkel. 1920 után jelentősen megcsappant az iskolák száma, megmaradt Békéscsaba, Hódmezővásárhely, Jászberény, Karcag, Kecskemét, Nagykalló, Pápa, Somogyszentimre, később társult Csermajor és Kehida. A szakiskolák tananyaga felülvizsgálatra szorult, mivel a gyakorlat aránya túlsúlyban volt. A jövőre nézve az elméletnek nagyobb szerepet kívántak adni, egyúttal a szakosodásban az oktatás hatékonyságának a növelését látták. A megyénkénti egy-egy iskola felelt volna meg a legjobban ezen szakoktatási szint iránti igénynek.

Intézményhez kötődő sajátos - időszakos - képzési formát valósított meg a téli gazdasági iskola. ${ }^{123}$ Honosításának kezdeményezője Serényi Béla (1866-1919) volt. Az első ilyen iskola Pápateszéren létesült. A fejlesztési terv kidolgozója fontos szerepet szánt ennek az iskolatípusnak, mert „[...] a legújabb mezögazdasági kutatásoknak gyakorlatban bevált eredményei igen jól és eredményesen terjeszthetök a téli gazdasági iskolák útján... [egyúttal] ... a gazdák nem nélkülözik legényfiaikat két éven át megszakitás nélkül $[\ldots]$ a tanitás a téli hónapokra esik, rendesen november elejétöl március végéig. " 124 Schandl Károly ideálisnak azt tartotta volna, ha minden nagyobb községben müködik ilyen iskola, mivel felállításuk nagyobb beruházást nem igényelt.

Az alsófokú szakoktatás - kizárólag gyakorlati hátterű - harmadik formáját a minden községben létesíthető mintagazdaságok jelentették volna, amelyek „[...] a legkisebb falvakban is arra (szolgálnának), hogy a földmüvelö nép példa után indulva, tanulja meg az okszerü gazdálkodást, s ezután is gyakorlati gazdasági oktatásban részesüljön."

Schandl külön említette az iskolán kívüli gazdasági oktatást is, amely rendszerességével, kiterjedt hálózatával nagy szolgálatot tehet a magyar agráriumnak. Népszerűsítő kiadványok, szaktanácsadás, gazdasági könyvtár, gazdasági tanfolyamok, külön hangsúlyozva a gazdasági nőnevelés szerepét, mind-mind lehetőséget kínált a gazdatársadalom szaktudásának a bővítésére.

Ez a Schandl Károly által jegyzett fejlesztési terv támpontot nyújtott a két világháború közötti évtizedek hazai mezőgazdasági szakoktatásában a követendő reformok körére, a szükséges korrekciók végrehajtására. Az 1927-ben papírra vetett elképzelések és a korszak agrároktatási rendszere között szembetűnő a hasonlóság.

\section{A mezögazdasági szakoktatás intézményei és müködésük}

$A z$ 1920. évi XXX. tc. - a tudományegyetemi közgazdaságtudományi kar létesítéséről - utólag, 1921. október 21 -én jelent meg, mivel az alapítás a korábbi 272/1920. M. E. sz. miniszterelnöki rendelethez kötődött. ${ }^{125}$ Ez utóbbi csak országgyűlési megerősítést jelentett. Ez egyúttal bizonytalanságot tükrözött, sőt sérelmet is kiváltott a műegyetem és a budapesti tudományegyetem - 1921-től Pázmány Péter Tudományegyetem - ré-

\footnotetext{
${ }^{123}$ Révai Nagy Lexikon XVI., Budapest, 1924, 759.

${ }_{124}$ Czvet Kovich Ferenc, Magyarország mezögazdasági szakoktatása, Budapest, 1930, 597-598.

${ }^{125}$ Csiki, i. m., 67.
} 
széről. A mezőgazdasági szakoktatás szempontjából sem volt kedvező, mert jelentőségét mellőzve, csak intézeti szinten működött. Továbbá „[...] az alapitó kormányrendelet is nyitva hagyta a Tudományegyetemhez való késöbbi csatlakozás vagy az önálló egyetemmé alakulás kérdését." $126 \mathrm{Az}$ 1930-as évek elején javult az egyetemi agrároktatás helyzete Magyarországon, bár ez a gazdasági világválságnak „köszönheto””, mivel pénzügyi nehézségek miatt a felsőoktatásban „ésszerűsítést” hajtottak végre és intézményi összevonásra került sor. ${ }^{127}$ Ennek eredményeként létrejött a Magyar királyi József Nádor Műszaki és Gazdaságtudományi Egyetem (1934-1949), amelyen belül önálló karként indult meg a mezőgazdasági és állatorvosi oktatás Az integráció legnagyobb vesztese az Állatorvosi Főiskola volt, amely már 1899 óta e néven működött, s önállóságot élvezve, európai rangú oktatási és kutatási színvonalat teremtett. Egyidejüleg elesett az FM támogatásoktól is. Az új egyetem felügyeletét a VKM látta el. A mezőgazdasági karon a kultusztárca a tanárok kinevezésekor mindig egyeztetett a földművelésügyi miniszterrel.

A négyéves képzés során szigorlati tárgyként szerepelt a mezőgazdasági kémia, gazdasági növénytan, közgazdaságtan, növényélet- és kórtan, háziállatok bonc- és élettana, mezőgazdasági ipar, földművelésügyi igazgatás, agrárpolitika, növénytermesztéstan, állattenyésztéstan, mezőgazdasági üzemtan és becsléstan. ${ }^{128} \mathrm{~A}$ diplomában „okleveles mezögazda" cím szerepelt. Az egyetemnek jogában állt doktori fokozatot adományozni. ${ }^{129}$ A tudományos cím elnyerésének a feltételei között szerepelt a doktori értekezés megvédése, valamint egy fö- és két melléktárgy szigorlatának letétele, továbbá egyéb formai elöírások teljesítése.

Az 1942. évi XVI. tc. értelmében a felsőfokú agrárképzés intézményei a következők voltak:

\section{FELSÖFOK}

\begin{tabular}{|c|c|c|c|c|c|}
\hline $\begin{array}{l}\text { Müszaki és Gazda- } \\
\text { ságtudományi } \\
\text { Egyetem Mezö- } \\
\text { gazdasági és Állat- } \\
\text { orvosi Karának } \\
\text { Mezögazdasági } \\
\text { Oszzálya }\end{array}$ & $\begin{array}{l}\text { Mezỏgazdasá- } \\
\text { gi Föiskola }\end{array}$ & $\begin{array}{l}\text { Gazdasági } \\
\text { Akadémia }\end{array}$ & $\begin{array}{l}\text { Müszaki és Gazda- } \\
\text { ságtudományi } \\
\text { Egyetem Közgazda- } \\
\text { ságtudományi Ka- } \\
\text { rának Gazdasági } \\
\text { Szaktanárképzö In- } \\
\text { tézete }\end{array}$ & $\begin{array}{l}\text { Gazdasági } \\
\text { Tanárképzó } \\
\text { Szaktanfo- } \\
\text { lyam }\end{array}$ & $\begin{array}{l}\text { Felsö tejgaz- } \\
\text { dasági és tej- } \\
\text { ipari Szak- } \\
\text { tanfolyam }\end{array}$ \\
\hline Budapest & $\begin{array}{l}\text { Magyaróvár } \\
\text { Kolozsvár }\end{array}$ & $\begin{array}{l}\text { 1. Debrecen } \\
\text { 2. Keszthely }\end{array}$ & Budapest & Kassa & Magyaróvár \\
\hline
\end{tabular}

Az 1942. évi XVI. tc. életbeléptekor fennálló mezőgazdasági szakoktatási intézmények Forrás: Kardos J. szerk. 2000. 134.

\footnotetext{
126 A magyar felsöoktatás évszázadai, i. m., 118.

127 A magyar felsöoktatás évszázadai, i. m., 127.

128 Csiki, i. m., 94-95.

129 Uo., 96.
} 
A gazdasági szaktanárképzés megindulását szintén 1934-ben szabályozták. ${ }^{130}$ Ezzel régóta húzódó probléma oldódott meg. A tényleges oktatás 1936-ban kezdődött el. Mivel a képzési lehetőség korlátozott volt, így az időközben visszakerült Kassai (középfokú) Gazdasági Tanintézet is szerephez jutott. A Gazdasági Tanárképzö Szaktanfolyam csak felsőfokú képesítéssel (okleveles mezőgazda, okleveles gazda) rendelkező gazdasági tanároknak és tanárjelölteknek nyújtott lehetőséget szaktanári képesítés megszerzésére. ${ }^{131} \mathrm{Az}$ intézmény a Földművelésügyi Minisztérium felügyelete alá tartozott. A hat hónapos tanfolyam egyrészt az elméleti és gyakorlati ismeretek felfrissítését szolgálta, másrészt pedagógiai jártasságot adott a jelölteknek. A sikeres vizsga letétele után véglegesítették őket az illető szakoktatási intézet tanári karában. ${ }^{132} \mathrm{Ez}$ a továbbképzési forma a közép- és alsófokú mezőgazdasági szakoktatási intézetek tanárainak volt fenntartva.

Az 1940-es évek elején Magyaróvárott a gazdasági akadémia, majd 1942-től a mezőgazdasági fóiskola az ottani M. Kir. Tejgazdasági Kísérleti Intézettel közösen, az FM felügyelete alatt, a leendő tejipari szakemberek részére továbbképző tanfolyamokat szervezett. A felsőfokú tejgazdasági és tejipari szaktanfolyamot még 1925-ben hozta létre a minisztérium, ${ }^{133}$ melynek elvégzésével a tejgazdaságban, tejiparban, szarvasmarhatenyésztő egyesületekben vezetői, tanári és felügyelői állások betöltésére nyilt lehetöség. ${ }^{134} \mathrm{~A}$ tanfolyamra beiratkozhattak akadémiai, egyetemi mezőgazdasági, állatorvosi, vegyészmérnöki és gépészmérnöki oklevéllel rendelkező szakemberek is, akik viszont a gyakorlattól mentesültek. ${ }^{135}$

A felsőfokú mezőgazdasági szakoktatás alapintézményei közé tartozott Debrecen és Keszthely. Debrecen szerepéről, törekvéseiről, az intézményi hálózatban elfoglalt helyéről már történt említés. Az a számos ellentmondás, amely a két világháború közötti évtizedek hazai agrároktatásában föllelhető, Debrecenben is megtalálható. A Dunántúl és az Alföld agrároktatási központjaiban, Keszthelyen és Debrecenben, az akadémiák feladata elsősorban arra irányult, hogy gyakorlati szakembereket képezzenek ki a hazai mezőgazdaság számára. Az 1934-ben bekövetkezett átszervezés kedvezőtlenül érintette az akkor még akadémiaként mủködő Magyaróvárt is, hiszen a „[...] változások kedvezményezettjei nem az akadémiák voltak, s ezt különösen Óvár nehezményezte."136 Jó néhány kérdés várt megoldásra és ez bizonytalanságot szült az érintettek körében. Az 1925-ben kiadott referátum A mezőgazdaság tudományos jellegü tevékenységének irányelvei címmel leszögezte, hogy "[...] az akadémiáknak nem a tudományos képzés, hanem a gyakorlati irányú ismeretek terjesztése és népszerüsitése a feladatuk. ${ }^{137} \mathrm{Ez}$ ellen

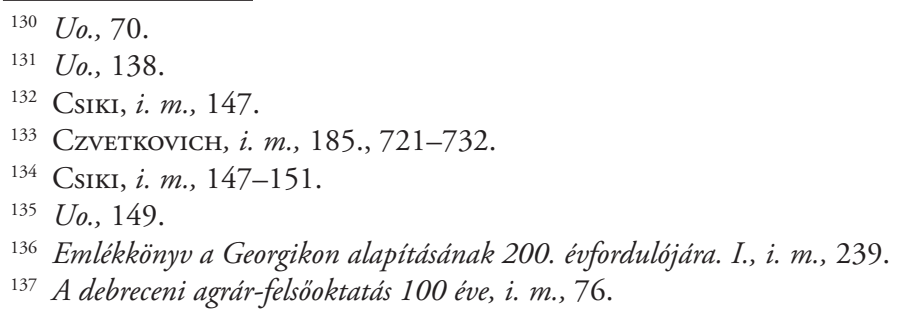


minden érintett intézmény tiltakozott. Rácz Mihály, a debreceni akadémia tanára által hangoztatott vélemény, miszerint a közgazdaságtudományi kar igyekszik a mezőgazdasági tudományos oktatást kisajátítani, összecsengett a gazdasági akadémiák álláspontjával. Ez az ellentét a későbbiek során is megmaradt, aminek az 1930-as évek közepén az OMGE is hangot adott, utalván a József Nádor Müszaki és Gazdaságtudományi Egyetem Mezőgazdasági Kara és az akadémiák közti - nem csillapodó - ellentétre. Az OMGE egy köztes megoldást igyekezett elérni, ami azt jelentette, hogy az egyetemnek módja van tangazdaság fenntartására. ${ }^{138}$ Egyúttal azonban nem szabad elzárkózni a gazdasági akadémiák fejlesztésétől sem, noha elismerte, hogy „[...] a jelenlegi viszonyok között az akadémiákat a régi minösitési joguktól úgyszólván teljesen megfosztották." Az OMGE valójában kiállt a Mủegyetem keretei között folyó oktatás mellett. Debrecen viszont a "kettös oktatási rendszer hivének mutatkozott”. ${ }^{139}$ E nézetnek Pallag többször is hangot adott, így Kesztyüs Lajos, akinek véleménye szerint: „[...] a fejlett mezögazdaságot csak tökéletes felsôfokú mezögazdasági szakoktatás hozhatja létre.” A gazdasági számviteltan tanára az akadémiák súlyát szerette volna növelni a magyar agrároktatásban, amelyek nemcsak a képzésben, hanem a tudományos kutatásban is tevékeny szerepet vállalnak. Az akadémiák és az egyetem közti ellentétek végigkísérik az egész korszakot. De azt az alapkérdést, hogy „[...] az agrár-felsöoktatás az akadémiák keretében nyerjen megoldást és ne az egyetemhez kapcsolódjék, ezen idöszak törekvései sem oldották meg." 140

1938-ban újra elötérbe került a gazdasági akadémiák oktatási profiljának a bővítése, különös tekintettel az üzemi, közgazdasági, piackutatási, értékesítési, szövetkezeti és tanácsadói háttér megteremtése érdekében, mert ezek a tárgyak csak lassan kaptak jelentőségükhöz méltó szerepet.

Az 1941-ben megtartott akadémiai értekezleten Debrecen memorandumot terjesztett elő Emlékirat a m. kir. gazdasági akadémiák föiskolai oktatásának fejlesztése tárgyában címen, ${ }^{141}$ javasolván azt, hogy "[...] azonos feltételek mellett lehetövé kell tenni a nemes verseny kialakitását a vidéki gazdasági föiskolák és a Müegyetem mezögazdasági osztálya között." A nemes versengés szükségességéről írt az OMGE hetilapja, a Köztelek is. ${ }^{142}$ Debrecen felvetését a többi intézet is támogatta. A Műegyetem ellenezte a négyéves oktatás bevezetését föiskolai keretek között. ${ }^{143}$ Végül az 1942. évi XVI. tc. egyértelművé tette a reform fokozatos bevezetését, s elmozdította a holtpontról a hosszú idő óta tartó vívódást, amely megosztotta a magyar agrár-felsőoktatást. A Debreceni Gazdasági Akadémia nem került bele az első körbe - Magyaróvár és Kolozsvár már az 1942/43. évi tanévtől - de Keszthellyel együtt arra lehetőséget kapott, hogy a beiratkozó elsőéves

\footnotetext{
138 Uo., 77.

139 Uo.

140 Uo.

141 Uo.

142 Elmélkedés a mezögazdasági fóiskoláról, Köztelek (1943/2), 28-29.

143 A debreceni agrár-felsöoktatás 100 éve, i. m., 78.
} 
hallgatók már a főiskolai tanterv alapján kezdjék meg tanulmányaikat. Pallag sajnálkozását fejezte ki amiatt, hogy az Alföld agrárképzési központja kiszorult a minőségi átszervezésből. Pedig a föiskolai képzés elindítása tovább növelte volna Debrecen vonzerejét - ami addig megvolt - nemcsak az Alföldön, hanem az ország más területein is. A megalapozott bizakodásra utal a beiskolázott hallgatók származási hely szerinti megoszlása 1868-1908 között, illetve az 1930-as évek elején. (1., 2. ábra)

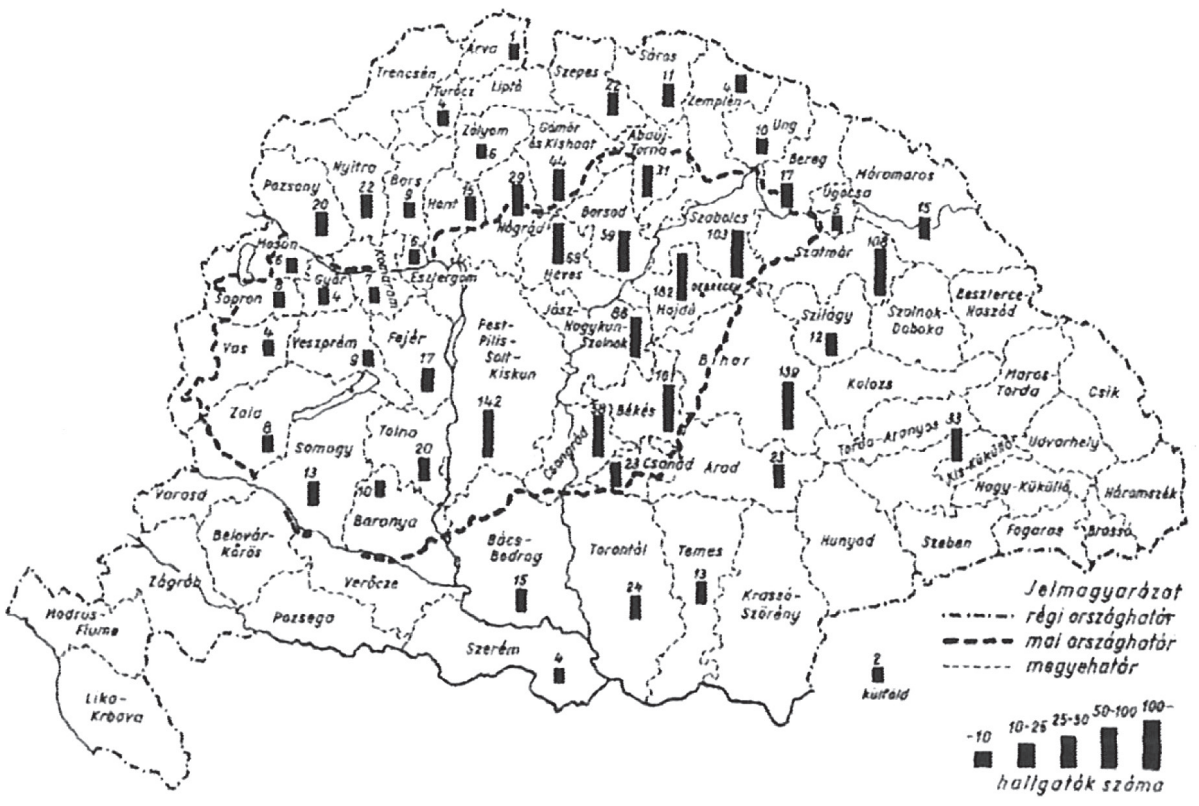

1. ábra. A debreceni mezőgazdasági akadémia hallgatóinak származási helye az 1868-1908 közötti években

(Forrás: Komoróczy Gy. szerk. 1968. 50.)

A korszak felsőfokú agrároktatásáról elmondható, hogy nem sikerült harmonikus egységet teremteni, ugyanakkor csorbát szenvedett Debrecen azon törekvése is, hogy szakoktatásának gyökereihez méltó módon, az Alföld agrárképzésében addig betöltött szerepének megfelelően - azt mintegy megkoronázva - föiskolai szinten képezze tovább a leendő szakembereket.

A hadszíntérré váló Tiszántúl, a háborús időszak, a politikai változások átértékelték Debrecen korábbi törekvéseit, egyúttal egy egészen más fejlődési pályára került a magyar agrároktatás is. Tóth Mihály, megbízott igazgató 1945. február elsejével, az országban elsőként, megindította az 1944/45-ös tanév második félévét. ${ }^{144} 1945$ fordulópontot jelentett az ország életében, s ez nem hagyta érintetlenül a nagy múltú magyar mezőgazdasági szakoktatást sem. 


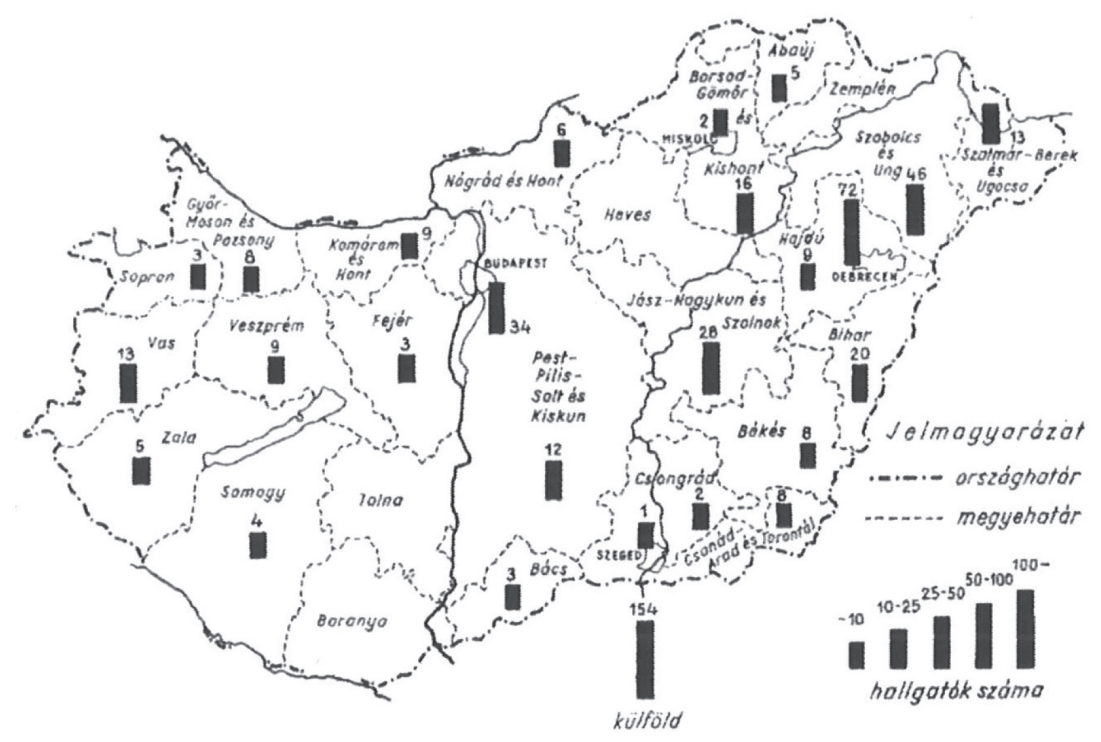

2. ábra. A debreceni mezőgazdasági akadémia hallgatóinak származási helye az 1930-1933 közötti években

(Forrás: Komoróczy Gy. szerk. 1968. 90.)

Az 1920-1944 között akadémiaként működő debreceni és keszthelyi intézetekben az alábbi tanszékek működtek: ${ }^{145}$

- növénytermesztési

- állattenyésztési

- üzemtani

- állategészségügyi és járványtani

- gazdasági növénytani és növénykórtani, valamint állattani

- kémiai

- müszaki

- közgazdasági és jogi

- gyakorlati

- külön tanszékcsoport: erdészettan, kertészet-szőlőművelés, öntözéses gazdálkodás, testnevelés.

1906-1944 között 120 tantárgyat oktattak a Debreceni M. Kir. Gazdasági Akadémián, ${ }^{146}$ ami jelzi, hogy az évtizedek során egyre nőtt az oktatott tárgyak száma. De a viszonylag bő kínálat mögött kétségtelenül legtöbbször a szakterület különféle megnevezése húzódott meg. ${ }^{147}$ Ennek ellenére csakugyan bővült a tantárgyak köre.

${ }^{145}$ CsIKI, i. m., 116.

146135 éves a debreceni agrár-felsöoktatás, i. m., 102-107.

147 Uo., 108. 
A hat féléves képzés során a kollokviumok és szigorlatok letétele után okleveles gazda minősítéssel kaptak diplomát a végzett hallgatók. ${ }^{148}$ Azon akadémiát végzett okleveles gazdának, aki mezőgazdaság-tudományi oklevelet kívánt szerezni, két féléves képzésen kellett részt venni a műegyetem mezőgazdasági karán, annak tantárgyaiból kollokválni és négy szigorlatot letenni. ${ }^{149} \mathrm{Ez}$ a lehetőség elvben adva volt a mezőgazdasági föiskolát végzett mezőgazdák számára is. ${ }^{150}$ (A négyéves képzés ugyanis csak 1942/43-ban indult meg, jóllehet a Müegyetem ebben a formában elvileg 1949-ig fennállt.) Doktori fokozatot (doctor agronomiae) kizárólag a M. Kir. József Nádor Műszaki és Gazdaságtudományi Egyetemen lehetett szerezni, ${ }^{151}$ a már ismertetett feltételek alapján. Ez az intézmény végezte a tudományos fokozat honosítását is. ${ }^{152}$

A mezőgazdasági főiskolát és gazdasági akadémiát végzett hallgató az egyetemi minősítő oklevél megszerzésével jogot nyert arra is, hogy doktori fokozatot nyerjen, az előírásoknak megfelelően. A mezőgazdasági oktatást végző felsőfokú intézmények között az „átjárhatóságra” lehetőség volt, különbözeti vizsgák letételével. A középfokú tanintézetekből nem, vagy csak kevés esély kínálkozott a továbbtanulásra. Ez egyik sajátos vonása volt az 1920-1944 közötti korszak hazai agrároktatásának. ${ }^{153}$

A gazdasági oktatás színvonalának javításáért tett erőfeszítések csalhatatlan jelének tekinthető, hogy 1936-ban a Gazdasági Szaktanárképző Intézet, 1942-ben pedig Kassán a Gazdasági Tanárképző Szaktanfolyam indította be kurzusait. ${ }^{154}$ A két intézménynek a tanári pályára való felkészítése különbözött egymástól. Míg a szaktanárképző intézetben az elméleti, ezen belül is a lélektani ismereteken volt a hangsúly, addig Kassán az előadások több mint 70\%-a a gyakorlati feladatok megoldására összpontosított. Ez utóbbi szélesebb körben értelmezte a gazdasági tanárok feladatkörét. Gondoljunk csak a népies gazdasági oktatásra, a szaktanácsadásra. A szaktanfolyam szakmaközelibb elvek és módszerek szerint folytatta tevékenységét. A Műegyetemhez kötődő szaktanárképző intézet egységes, államilag elismert pedagógiai ismereteket adott a hallgatóknak. „Hiányosságai” ellenére azonban megadta a lehetőséget a szakoktatásban működő tanárok számára a pedagógiai diploma megszerzésére. Ezzel szemben Kassa kizárólag gyakorlatra épülö, szakágazati érvényességü bizonyítványt adott és jóllehet csak az agráriumban, de azon belül bővebb esélyt kínált a gazdasági tanároknak. Ez abból adódik, hogy a kassai tanfolyam okleveles mezőgazda, okleveles gazda képesítésü tanárok, tanárjelöltek továbbképzését vette számításba. ${ }^{155}$

\footnotetext{
${ }_{148}$ CsIKI, i. m., 122.

149 Uo., 125-128.

${ }_{150}$ CsIKI, i.m., 113.

151 Uo., 96.

152 Uo., 102.

153 Rakaczkiné Tóth Katalin, Az agrár-szaktanárképzés története az 1930-as évektöl napjainkig, Gödöllö, 2002, 42.

154 CsIKI, i. m., 128; RAKACZKINÉ, i. m., 98-100.

155 CsIKI, i. m., 38
} 
A mezőgazdasági szaktanárképzés előfutárának tekinthető az 1910-ben a Komáromi Gazdasági Szaktanítóképző és a Kecskeméti Gazdasági Szaktanítónő-képző Intézet felállítása. ${ }^{156}$ Középfokú intézményként a gazdasági népiskolák számára biztosította az okleveles tanítók és tanítónők szakmai továbbképzését. A szaktanítóképzés rendszerében az 1920-as évek végén történt változás. ${ }^{157}$ Kezdetben az okleveles tanító(nő) gyakorlati tanfolyamokon való részvétellel, ezenfelül földművesiskoláknál kétéves ösztöndíjasként, majd újabb kétéves szaktanító(nő)i továbbképzés után kapta meg bizonyítványát. Később ez annyiban módosult, hogy a Debreceni Gazdasági Akadémián - rendkívüli hallgatóként - három év alatt szerzett képesítést. 1929-től viszont az alapképzésnek a gazdasági akadémia számított és a jelölt különbözeti vizsga letétele után került a kiskunfélegyházi tanítóképzőbe, ahol az ötödik évfolyam elvégzésével szerezhetett néptanítói oklevelet. Ez előrelépést jelentett, mivel a szaktanítóképzés már főiskolai végzettségre épült. (1920 után Kecskemét adott otthont a határon túlra került komáromi intézetnek is.) ${ }^{158}$

Az 1920-1944 közti évtizedek alatt épült ki a középfokú mezőgazdasági szakoktatás iskolahálózata is. Az 1940-es évek elején a következő helyeken működött középfokú gazdasági tanintézet és mezőgazdasági szaktanácsadó állomás Szarvas (1927), Székesfehérvár (1938), Kassa (1939-a gazdasági akadémia helyett), Debrecen (1940), Marosvásárhely (1941), Újvidék (1941), Sepsiszentgyörgy (1942). ${ }^{159}$ Ezek az intézetek az FM hatáskörébe tartoztak. ${ }^{160}$ Feladatuknak tekintették, hogy a birtokos vagy bérlő családok gyerekeivel megismertessék a saját tulajdonú vagy bérletként kezelt földbirtokon az önálló gazdálkodás „fogásait”. Ezek az intézetek szaktanácsadással is foglalkoztak, és kivették részüket a szakismeret népszerüsítéséből is. A négyéves tanulmányok befejezése után képesítő vizsgára került sor, amihez közismereti tárgyak (magyar nyelv és irodalom, történelem) is tartoztak. A végzett hallgatókat a „képesített gazda” cím illette meg.

A mezőgazdasági középiskolából - amely eredetileg felső-mezőgazdasági iskolaként jött létre, s 1938-tól kapta új nevét - az 1940-es években az ország különböző településein tizenegy működött: Bácsalmás (1938), Berettyóújfalu, Békéscsaba (1923), Kecskemét (1936), Orosháza (1912 - állami), Gyöngyös (1925 - katolikus egyházi), Csurgó, Szeghalom (református egyházi), Budapest (1926 - városi) ${ }^{161}$ A leányok részére fenntartott intézmények: Kiskunfélegyháza (1938 - Constantinum), Sopron (Vicentianum), mindkettő a katolikus egyház kezelésében. Ezek az iskolák a VKM felügyelete alatt végezték oktatói tevékenységüket. Bár a végzett hallgatóknak lehetőségük volt továbbtanulásra, az iskola alapvető feladatából adódóan a tanulók döntő hányada a saját birtokon való gazdálkodást tekintette elsődleges céljának. A két középfokú iskolatípust összehasonlítva (tanterv, tanmenet), kitűnik, hogy amíg a gazdasági tanintézetekben a

\footnotetext{
156 Rakaczkiné, i. m., 37-38.

157 Uo., 39-40.

158 CsIKI, i. m., 151.

159 Uo., 74.

160 Uo., 154-158.

161 Uo., 158-164.
} 
szakismereti és közismereti tárgyak jól elkülönülnek (az előbbiek jellege jobban kidomborodik, magas heti óraszámmal), addig a mezőgazdasági középiskoláknál a mezőgazdaságtan egyes területei „csupán” az oktatott tárgyak egyikét jelentik, alacsonyabb heti óraszámmal. Azon felül ez utóbbinál hangsúlyt helyeztek az idegen nyelvek oktatására is. A mezőgazdasági középiskola befejezése érettségi vizsga letételével zárult.

Részben középfokú továbbképzést, illetve szakosodást kínáltak a tejipari szakiskolák, melyek szaktanácsadással is foglalkoztak. Közéjük tartozott Csermajor, Marosvásárhely és Munkács, ahol három év leforgása alatt átfogó ismeretet kaptak a hallgatók a tejgazdaság területéről. ${ }^{162}$

Putnokon ${ }^{163}$ gazdasági leánynevelő működött, s hasonló célt szolgált a fôvárosi intézet is. ${ }^{164} \mathrm{~A}$ VKM felügyelete alá tartozott a fentiekhez hasonló rendeltetésủ Aminozi Károly (pesti vaskereskedő 1877. évi végrendelete alapján) által alapított nőnevelő intézet is. ${ }^{165}$ Szintén a kulturális tárcához tartoztak a nők háztartási és gazdasági ismereteit bővítő - zömmel - egyéves tanfolyamok is.

Az alsó fokú mezőgazdasági szakoktatás jellegét a mezőgazdasági szakiskolák határozták meg (a korábbi földművesiskolák). ${ }^{166}$ Rendeltetésüket illetően a következő szempontoknak kellett megfelelniük: „[...] elsösorban saját gazdasággal vagy bérlettel biró gazdaifjaknak, másodsorban gazdasági altiszti pályára készülö, gazdaságban nevelkedett ifjaknak foglalkozásuk szakszerü üzéséhez feltétlenül szükséges elméleti és fóként gyakorlati gazdasági ismeretek megszerzéséhez módot nyújtani." 167 Az 1930-as években a következő településeken folyt ilyen jellegü oktatás: Békéscsaba (1896), Csermajor (1920), Hódmezővásárhely (1896), Jászberény (1896), Karcag (1899), Kecskemét (1895), Kehida (1927), Nagykalló (1911), Pápa (1893), Somogyszentimre (1886), Szekszárd (1930). Egy évtized alatt azonban változott a hálózat képe, mivel kiesett Somogyszentimre és Kecskemét, de közben belépett Csíkszereda. ${ }^{168}$ Az 1928-ban megindult szervezés ellenére csak terv maradt Vas megyében a füteleki iskola megnyitása. ${ }^{169}$ Ezekben az FM felügyelte intézetekben, ahová a 17. életévüket betöltött fiatalokat vették fel, a tanítás ingyenes volt. ${ }^{170}$ Szakvizsgával zárult a kétéves képzés.

A háborús évek és a front közeledte megakadályozta, hogy Gyulán megnyissa kapuit egy öntözésre szakosodott, Alsóvereckén pedig egy havasi gazdálkodásban való jártasságot nyújtó szakiskola.

Az 1920-1944 közötti évtizedekben a téli gazdasági iskolákból hatvan állami, három felekezeti és egy pedig társulati fenntartásban szolgálta a hazai alsó fokú gazdakép-

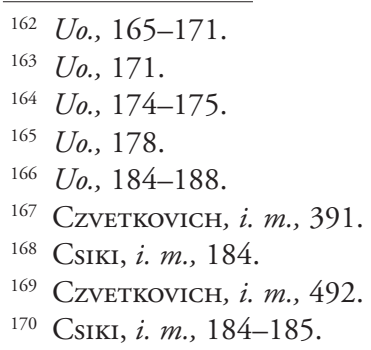


zést. ${ }^{171}$ Debrecen környékén a következő településeken létesültek ilyen intézetek: Berettyóújfalu, Hajdúdorog, Mátészalka, Tiszafüred, Tiszalök. ${ }^{172}$ A felekezeti fenntartásúak közé tartozott: Csurgó (református), Kézdivásárhely (katolikus), Székelykeresztúr (unitárius), s társulati kezelésben Beszterce (szászok). A kétéves képzés a téli hónapokat vette igénybe: november 1-től március 15-ig. A gyakorlati terepet a saját (szülői) gazdaság biztosította.

A korszak idejétmúlt eszmei-politikai rendszere egyik hajtásának tekinthető vitézi rend is fenntartott külön mezőgazdasági szakiskolát Örkényben, amely magánalapítványból jött létre. ${ }^{173}$

A téli gazdasági tanfolyamok tartama három, illetve két hónapra, a november 15-e - március 15-e közti időszakra terjedt ki. ${ }^{174}$ Ez a képzési forma tekinthető a legkevésbé iskolaszerűnek, akár tartalmát, akár szervezését, lefolyását tekintve. Viszonylag nagy számban látogatták a gazdák - a mezőgazdasági idényen kívüli időben - és a záróvizsgával elnyerték a jogot az „ezüstkalászos gazda” cím és jelvény viselésére. ${ }^{175} \mathrm{~A}$ téli gazdasági iskolák és tanfolyamok népszerüek voltak a parasztság körében, hiszen ezen képzési forma révén jutott el hozzájuk a leggyorsabban a korszerű gazdálkodás ismerete. A túlfütött háborús konjunktúra évei alatt számos, addig kevésbé termesztett növényféle honosodott meg a paraszti termelésben, ami új gépi eszközzel és termesztési módszerrel párosult. Gondoljunk pl. az olajtartalmú növények termesztésének térhódítására, az ekekapa rendszeressé váló használatára vagy a burgonya töltögetésére stb.

A szakoktatási hálózat körébe tartozott még néhány, általában alsó fokú képzést folytató intézmény, így a tejipari tanfolyamok, háziasszonyképző iskolák (Debrecenben is), háztartási vándortanfolyamok (változó székhellyel). ${ }^{176}$ Bő választékot kínáltak az olyan előadássorozatok, amelyek részben rendszerességgel, jórészt azonban változó színhellyel és alkalomszerűen vették ki részüket a szakképzésből. ${ }^{177}$

A Debrecen székhellyel működő Tiszántúli Mezőgazdasági Kamara, a többi kamarához hasonlóan, szintén szerepet vállalt a mezőgazdasági szakismeret-terjesztésből. ${ }^{178}$ Ezek a rövid tartamú tanfolyamok alkalmai jellegüek voltak. Egyúttal azonban több évig működő, állandó székhellyel bíró téli gazdasági iskolákat is létesített a TiMeKa. 1925-ben Hajdúnánáson, Kisújszálláson és Orosházán nyílt meg téli gazdasági iskola. Ez a hullám folytatódott 1926-ban, amikor Balmazújvároson, Derecskén és Fehérgyarmaton létesült hasonló intézmény. Sajnos ez a folyamat megszakadt a pénzügyi források hiánya miatt. Sőt a már működő iskolákat is be kellett zárni (1927).

${ }^{171}$ Uo., 188.

172 Uo., 188-189.

173 Czvetrovich, i. m., 697-718., Csiki, i. m., 195.

${ }_{174}$ CsIKI, i. m., 199.

175 Uo., 202.

176 Uo., 203-208.

177 Czvetкovich, i. m., 839-857.

178 Uo., 888-892. 
A kamara a gazdasági ismeretterjesztésnek más útját kereste, így „[...] a kamara székhelyén [...] a kerület sok más helységében, a legkülönbözöbb mezögazdasági ágakból, számos - gyakorlati bemutatókkal és tanulmányi kirándulásokkal egybekötött - tanfolyamot rendezett a Tiszántúli Mezögazdasági Kamara." 179 Példaként csak néhány tanfolyam 1920-1930 között:

- szőlő-borgazdasági, gyümölcskertészeti tanfolyam - Debrecen (1923), Nyíregyháza (1924);

- méhészeti - Debrecen (1923);

- szőlő- és mustfeldolgozási - Debrecen, Nyíregyháza (1925);

- növényvédelmi -Debrecen, Hajdúszoboszló (1926);

- sziktalaj-javítási - Kisújszállás, Kunhegyes, Püspökladány (1926);

- téli gazdasági tanfolyamok (4 hónapos) - Balmazújváros, Hajdúnánás, Orosháza;

- kéthetes gyümölcsészeti - Nyírábrany, Kunhegyes, Kisvárda, Mándok;

- téli gazdasági tanfolyam - Biharkeresztes (1928), Nyíregyháza (1929).

A TiMeKa 1926-ban indította útjára mezőgazdasági gépészeti vándoriskoláját. A különböző színhelyeken tartott mezőgazdasági szakelőadások is népszerűek voltak a gazdák körében. Lényegében az állat- és terménykiállítások rendezése is az ismeretterjesztést szolgálta, ahol szakelőadások foglalkoztak az agrárium időszerű kérdéseivel. A Nyíregyházán létrehozott homokjavító kísérleti gazdaság szintén a TiMeKa érdemei közé tartozott, amely 1929-től rendszeresen otthont adott a téli gazdasági tanfolyamoknak. A kamarai kerület 14 településén ingyenes gazdasági kölcsönkönyvtárat hoztak létre, melyeknek állományát az FM adományként bocsátotta rendelkezésükre.

A szakismeret-terjesztést, a szakirodalom művelését biztosította a TiMeKa hivatalos lapja a "Tiszántúli Gazdák" címü szaklap is, amely havonta kétszer, 1500 példányban jelent meg. Ugyanez a szándék vezérelte az „Alföldi Magvetö” címmel megindított könyvsorozatot is, amely a magasabb képzettségủ agrárszakemberek számára adott hasznos tudnivalókat.

Az általános mezőgazdasági szakoktatási intézményeken kívül - a teljesség kedvéért - ildomos néhány olyan intézetről is szót ejteni, ahol elsősorban alsó- és középfokú oktatás folyt 1920-1944 között. ${ }^{180}$ Az erdőgazdasági szakiskola az 1924/25. évi tanévtől már Esztergomban kezdte meg az iskolai évet. Középfokú intézetnek számított. Erdőőri és vadőri oktatásnak adott otthont Szeged (Királyhalom) és Esztergom. A kertészeti szakoktatás terén Baján a kertészképző intézet tárgyai középfokú elővégzettségre épültek. A Budaörsön lévő állami törzsgyümölcsös egyúttal kertészsegédeket is képzett. Szőlészeti és borászati szakiskola található Egerben, Kecskeméten, Sopronban és Tarcalon. Legalább négy középiskolai osztály volt a felvétel feltétele a Gödöllőn működő baromfitenyésztő szakiskolán, ahol egyéves oktatás volt. A Gödöllőn lévő állami méhészeti gazdaság felvállalta időszaki tanfolyamok szervezését és a kétéves oktatásra épülő méhészmunkás-képzést.

179 Uo., 888.

180 Uo., 916-924. 
Az alsófokú szakoktatás terén, a közoktatás keretében a mezőgazdasági népiskolák meghatározó szerepet játszottak, melyeknek gyökerei visszanyúlnak 1868-hoz, a népiskolai törvény előírásaihoz. ${ }^{181} \mathrm{Az}$ ún. ismétlő-iskolák a 12-15 éves gyermekek számára kötelezőek voltak. A 60.764/1896. VKM rendelet alapján a 19. század végén már gazdasági ismétlőiskola néven folytatták tevékenységüket. Az 1902. évi törvény pedig részletesen szabályozta az iskolai szervezet müködését. ${ }^{182} 1920$ után az ezen iskolatípushoz tartozó intézetek száma ugrásszerűen megnőtt. A gazdasági ismétlőiskola az elemi iskolára épült és a tankötelezettség határán belül alsófokú agrárismeretek oktatásában részesítette a tanulókat, kötelező érvénnyel. Az 1930-as években már 1411 ilyen típusú iskola létezett az országban, mintegy 120 ezer tanulóval. Jórészt szakképzett tanító(nő) $\mathrm{k}$ foglalkoztak a gyermekekkel. 1921-ben az átszervezés révén megváltozott az iskolák elnevezése is: önálló gazdasági népiskolákként folytatták munkájukat, ${ }^{183}$ természetesen a korábbihoz hasonlóan a VKM felügyelete alatt. Az újabb változást a 109.388/1938. IX. sz. rendelet jelzi, amely az elnevezésben is tükröződött: mezőgazdasági népiskola. ${ }^{184}$ Az 1930-as évek végén egy-egy iskolára több mint 400 fös tanulói létszám jutott a hároméves képzés során. A rendszeres képzésen túl ezek az iskolák tanfolyamokat is szerveztek, amelyre önkéntes alapon toborozták a tanulókat Az egyes iskolák átlagosan 26,7 kat. hold gyakorló területtel rendelkeztek, amely különböző művelési ágak között oszlott meg. A kis „tangazdaságok állatállománya elsösorban szarvasmarhából, sertésböl és baromfiakból állt". Számos helyen még tenyészállat-neveléssel is foglalkoztak. A merőgazdasági népiskolák száma a megnagyobbodott ország területén az 1940-es évek elején $66 \mathrm{db}$ volt, melynek fenntartói megoszlása a következő volt.

- állami 24,

- községi 40,

- kat. egyházi 1.

- alapítványi 1.

Az iskolák megnevezésénél csak Debrecen és környékére szorítkozunk: Balmazújváros (községi - 1939), Berettyóújfalu (községi - 1905-1926 között, a kertészet előtérben), Debrecen I. (községi - Mikepércsi út 10. - 1905), Debrecen II. (állami - Kishegyesi út 3. - 1908), Derecske (községi - 1901), Hajdúböszörmény (községi - 1938), Hajdúszoboszló (állami - 1898), Kaba (községi - 1906), Kornádi (községi - 1908), Nádudvar (községi - 1899). ${ }^{185}$ A mezőgazdasági népiskola kétéves képzést adott. A szorgalmi idő október 15-e - április 15-e közé esett. A nyári időszakban a tanulók gyakorlaton vettek részt. ${ }^{186}$

Összegzésként az 1920-1944 közti évtizedek mezőgazdasági szakoktatásáról elmondható, hogy lépések történtek az 1867-1918 közé eső korszak során felgyülemlett problémák megoldására, amire a békekötések nyomán kialakult politikai helyzet,

\footnotetext{
${ }^{181}$ CsIKI, i. m., 60.

182 Uo., 61.

183 Uo., 81.

184 Szakoktatási évkönyv, szerk. SchöPflin-PogÁNy Károly, Budapest, 1940, 147-151.

185 Szakoktatási évkönyv, i. m., 151-174.

186 CsIKI, i. m., 213-215.
} 
s annak nyomán bekövetkező gazdasági változások is ösztönözték a magyar államot. A területvesztés, az ország agrárpotenciáljának módosulása a szakképzés fejlesztésére, a parasztság tömegeinek szakmai fölzárkóztatására is serkentette a kormányt, a földmüvelési tárcát. Mindez beleillett abba a törekvésbe, melynek nem titkolt szándéka mögött a területi revízió szellemi hátterének a megteremtése húzódott meg. Ez Klebelsberg Kunó kultúrpolitikájában fogalmazódott meg. Természetesen ez mit sem von le pl. a mezőgazdasági szakoktatás fejlesztése terén elért eredmények értékéből. Ellentmondásossá teszi azonban a képet az, hogy a magyar agrárium birtokpolitikája változatlan maradt és a mezőgazdasági termelés szerkezete sem igazodott az európai agrárpiaci viszonyokhoz. E téren nem adott elég lendítő erőt az 1929-1933 között lezajlott gazdasági világválság sem.

A mezőgazdasági szakoktatás fejlődését mindenesetre jelzi, hogy már egyetemi szinten is „betagozódott” a magyar oktatásba. Erősödött a gazdasági akadémiák szerepe, amely még ellentéteket is szült az egyes intézmények között, sőt a VKM és az FM között is. Sikerként könyvelhető el a szaktanárképzés megteremtése. Kiépült a középfokú gazdasági tanintézetek hálózata, amelyből a közoktatás is kivette a részét. Többszöri átszervezéssel olyan alsófokú szakoktatási iskolarendszert igyekeztek létrehozni, amely a gazdálkodók széles rétegeihez eljuttatja a korszerű gazdálkodás elméleti, gyakorlati ismereteit. Tanfolyamok sokaságát szervezték, amiből kivették részüket a mezőgazdasági kamarák is. Egyidejűleg bevonták az ismeretterjesztésbe a rádiót is. A háborús konjunktúra évei alatt meghozott döntések azonban az idő rövidsége miatt már csak részben éreztették hatásukat, hiszen az ország területe hadszíntérré vált és annak elmúltával lezárult egy korszak.

1945 után a mezőgazdasági szakoktatásban számos olyan változás következett be, melynek gyökerei visszanyúlnak a megelőző évtizedek terveihez, részben megvalósult elképzeléseihez.

\section{Összefoglalás}

A több mint egy évezredes hazai oktatás történetében a mezőgazdasági szakoktatás viszonylag későn jelent meg. Hosszú évszázadokon keresztül a gazdálkodás, a sorjázó nemzedékek tapasztalati kultúrájára épült. A korszerü mezőgazdaság kibontakozása, a tudomány eredményeire hagyatkozó gazdálkodás, a fejlődés követelményeként 17-18. században egyre nagyobb szerepet kezdett játszani. Mindez tudományos ismereteket igényelt, ami ösztönözte a mezőgazdasági oktatás megszületését és térhódítását, vagyis az oktatási hálózat kiépítését. Magyarországon ezen a téren előkelő helyet foglal el a keszthelyi Georgikon, ahol 1797-ben kezdetét vette a mezőgazdasági képzés. A gyakorlati oktatást célzó Szarvas pedig 1779-ben nyitotta meg kapuit. Az állatorvoslás már 1789-ben ismert volt Európában. Magyaróvár 1818-tól szolgálja a hazai mezőgazdasági kultúrát. 
Debrecen szintén előkelő helyet foglal el ebben a rangsorban, amely 2018-ban ünnepli fennállásának 150 éves évfordulóját. Az első azon intézmények sorában, amely egy város polgárainak kezdeményezéseire indult útjára, állami támogatással. Ezzel új korszak köszöntött be 1867 után, amikor a központi hatalom vállalt szerepet az oktatási intézmények felállításában. Az addigi magánérdekek, az egyéni törekvések a mezögazdasági intézmények létesítésében háttérbe szorultak. Az 1868-ban kapuit megnyitó debreceni tanintézet gyorsan felzárkózott a korábbi alapítású szakképzés fellegvárai mellé, és rövid idő alatt rangot vívott ki magának hazai és nemzetközi téren egyaránt. A Tiszántúl metropolisának felsőfokú mezőgazdasági szakképzése hosszú utat tett meg napjainkig az oktatás, kutatás terén. 